\title{
Shock Transmission through Cross-Border Bank Lending: Credit and Real Effects
}

\author{
Galina Hale \\ Federal Reserve Bank of San Francisco \\ Tumer Kapan \\ International Monetary Fund \\ Camelia Minoiu \\ International Monetary Fund \\ The Wharton School \\ February 2016 \\ Working Paper 2016-01
}

http://www.frbsf.org/economic-research/publications/working-papers/wp2016-01.pdf

\section{Suggested citation:}

Hale, Galina, Tumer Kapan, Camelia Minoiu. 2017. "Shock Transmission through Cross-Border Bank Lending: Credit and Real Effects.” Federal Reserve Bank of San Francisco Working Paper 2016-01. http://www.frbsf.org/economic-research/publications/working-papers/wp2016-01.pdf

The views in this paper are solely the responsibility of the authors and should not be interpreted as reflecting the views of the Federal Reserve Bank of San Francisco or the Board of Governors of the Federal Reserve System. 


\title{
Shock Transmission through Cross-Border Bank Lending: Credit and Real Effects*
}

\author{
Galina Hale $\quad$ Tümer Kapan ${ }^{\ddagger} \quad$ Camelia Minoiu ${ }^{\S}$
}

June 15,2017

\begin{abstract}
We study the transmission of financial shocks across borders through international bank connections. Using data on cross-border interbank loans among 6,000 banks during 1997-2012, we estimate the effect of banks' direct and indirect exposures to banks in countries experiencing systemic banking crises ("crisis exposures") on profitability, credit, and the performance of borrower firms. We show that direct crisis exposures reduce bank returns and tighten credit conditions through lower loan volumes and higher rates on new loans. Indirect crisis exposures amplify these effects. Crisis exposures reduce firm growth and investment even in countries not experiencing banking crises themselves, thus transmitting shocks across borders.
\end{abstract}

JEL Codes: F34, F36, F6, G01, G21

Keywords: cross-border interbank exposures, banking crises, shock transmission, bank loans, real economy

\footnotetext{
* We thank Franklin Allen, Olivier Blanchard, Marianna Caccavaio, Charles Calomiris, Stijn Claessens, Ricardo Correa, Ben Craig, Mathias Drehmann, Michael Gofman, Linda Goldberg, Itay Goldstein, Mathias Hoffmann, Graciela Kaminsky, Andrew Karolyi, Arvind Krishnamurti, Augustin Landier, Luc Laeven, Steven Ongena, José-Luis Peydró, Andrea Presbitero, Robin Lumsdaine, Alessandro Rebucci, Peter Sarlin, Philipp Schnabl, Enrico Sette, Livio Stracca, Kathy Yuan, Gaiyan Zhang, Larry Wall, and audiences at numerous seminars and conferences for helpful comments. We are grateful to Nicola Babarcich, Julia Bevilaqua, Peter Jones, and Elliot Marks for their research assistance at different stages of this project. This is a significantly revised version of a paper previously titled "Crisis transmission in the global banking network" (IMF Working Paper No. 16/91). The views expressed in this paper are those of the authors and do not represent those of the Federal Reserve System, the IMF, or their policies.

${ }^{\dagger}$ Federal Reserve Bank of San Francisco. Email: galina.b.hale@sf.frb.org

${ }^{\ddagger}$ International Monetary Fund. Email: tkapan@imf.org

§International Monetary Fund and The Wharton School. Email: cminoiu@wharton.upenn.edu
} 


\section{Introduction}

The interconnectedness of global financial intermediaries played a major role in the 2007-2009 financial crisis. As William Dudley, President of the Federal Reserve Bank of New York, remarked, the negative spillovers and externalities of bank defaults for the financial system as a whole become "disproportionately high in the case of large, complex, and interconnected firms" (Dudley, 2012). Ben Bernanke, Chairman of the Board of Governors of the Federal Reserve System, argued that interconnectedness "has the potential to magnify shocks to the financial system" (Bernanke, 2013). In recent years, academia and policy institutions have called for more research on the linkages that transmit distress from one financial firm to another and ultimately impact the broader financial system. Such research should "ideally include the interactions of interbank exposures with the real economy" (Tumpel-Gugerell, 2009).

Yet, despite a burgeoning literature on financial stability and systemic risk, little is known about the real effects of interbank connections, especially in the international context. In this paper, we provide new evidence on the international propagation of shocks through interbank exposures by exploiting detailed data from the cross-border loan market. Specifically, we compute timevarying exposures spanning 15 years for more than 6,000 banks that engage in cross-border lending to other banks. Our goal is to analyze how financial shocks in foreign markets are transmitted through this global web of bank connections to affect banks' profitability and lending decisions, as well as the real economy. We estimate the effects of direct and indirect exposures (one and two steps away from the origin of the shock) to banks in countries that experience systemic banking crises. We find that exposures to systemic banking crises in foreign markets affect bank returns, bank lending (volumes and spreads), and the investment and growth of firms that borrow from exposed banks. In particular, we document a statistically significant and economically meaningful negative impact of direct exposures to crises on bank profits, lending decisions, and firms' investment and growth. There is also an additional negative impact on bank profitability and lending of indirect exposures to banks in crisis countries. Our results further indicate that banks with exposures to a foreign country in crisis reduce lending to firms in other foreign countries, acting as a channel of international shock transmission from crisis countries to countries that are ex-ante healthy.

To construct measures of cross-border interbank exposures, we exploit data from the market for large bank loans (to bank, corporate, and sovereign borrowers), most of which are syndicated. ${ }^{1}$

\footnotetext{
${ }^{1}$ To be precise, in our dataset three quarters of all loans are syndicated and rest are single-lender loans. For simplicity, in the remainder of the paper we refer to all loans as "syndicated loans."
} 
Syndicated loans have been extensively studied in finance, yet the interbank segment of this market remains underexplored. For instance, it is well known that loans extended by bank syndicates are an important source of funding for corporations and sovereigns (Ivashina and Scharfstein, 2010; Sufi, 2007). What is less known is that these loans, with an average volume of 175 million U.S. dollars and tenor of 3 years, account for almost one third of all cross-border loans to banks. They are also a sizeable funding source for banks. Both advanced economy and emerging market banks tap this market to broaden their funding sources and support balance sheet growth. Syndicated loans from banks represent a sizeable share of cross-border wholesale funding especially for banks from emerging markets. Interbank loans account for about $10 \%$ of global syndicated loan volume, which reached a pre-crisis peak of 4.5 trillion U.S. dollars in 2007.

Based on loan-level data we construct interbank exposures at the bank level using information on the identity and country of each lender and borrower, as well as the amount and maturity of each loan deal. We draw on Dealogic's Loan Analytics database, which comprises more than 170,000 loans extended during 1990-2012 to bank, corporate, and sovereign borrowers in approximately 200 countries. Of these, almost $10 \%$ of loans are granted by banks to banks for a total of 6,083 banks. We start by computing bank-level exposures to individual foreign banks. We then combine these bilateral exposures with dates of systemic banking crises in the countries of borrower banks. This gives us exposures to banks in countries that are experiencing (or not) a systemic banking crisis. Specifically, we calculate both direct (first-order or one step away) and indirect (second-order or two steps away) exposures to banks in countries that are experiencing a crisis, which we call "crisis exposures," as well as exposures to banks in countries that are not experiencing a crisis, that is, "non-crisis exposures." ${ }^{2}$ Finally, we combine these data with bank and firm balance sheet information.

This novel dataset enables us to document, for the first time, the real effects of shock propagation through cross-border interbank connections, which is the key contribution of our paper. Our analysis documents a strong link from banks' crisis exposures to their profitability, lending decisions, and the performance of borrower firms. First, we focus on the impact of crisis exposures on bank

\footnotetext{
${ }^{2}$ The interbank exposures studied here are closely related to the credit risk associated with lending to foreign banks. While outright bank defaults are rare, it is common for the debt of distressed banks to be restructured, which leads to direct losses for the creditor. Additionally, interbank exposures may reflect risks that go beyond idiosyncratic borrower risk and are associated with lending to foreign markets in general. Our crisis exposure measures are constructed using an indicator of country-level systemic banking crises in a foreign market, capturing system-wide risks rather than individual counterparty risks. Even in the absence of bankruptcies and outright defaults of individual counterparties, a bank's financial strength can be affected adversely by the emergence of bad economic, financial, or political news about the foreign markets to which it is exposed. As a consequence of such news, the bank may experience a loss of business from the affected market and from similar markets, a higher cost of funds, and even a creditor run.
} 
profitability. Bank profitability is of particular interest because low profits are associated with distorted financial risk-taking incentives (Demsetz, Saidenberg and Strahan, 1996; Keeley, 1990), bank failures, impaired financial intermediation, and sluggish growth (IMF, 2016). Second, we assess the impact of crisis exposures on banks' fundamental function of financial intermediation. The link between financial system conditions and economic activity was formalized in the financial accelerator framework developed by Bernanke, Gertler and Gilchrist (1999), who emphasized that the price of external financing is a function of firms' financial position. Weak firms have to pay a higher "external finance premium" to raise funds than strong firms. The 2007-2009 financial crisis showed that a similar "external finance premium" exists for banks, generating a link between their financial strength and their ability to raise market funding (Bernanke, 2007). As a consequence, shocks that reduce bank profitability also hinder their ability to raise funds to lend, with potential adverse effects for financially-constrained firms and the real economy. To examine whether crisis exposures translate into less bank credit to firms, we use data on corporate loans granted to individual borrowers. Third, we investigate whether cross-border crisis exposures ultimately impact the real economy by examining the investment and growth of individual firms that borrow from the banks in our sample.

We present three sets of results. First, we show that a larger number of crisis exposures is associated with lower bank profitability, measured by return on assets (ROA), return on equity (ROE), and net interest margins (NIM) during 1997-2012. We use granular fixed effects to compare the performance of banks within a given country and year and identify effects that are on top of general declines in bank profitability that might be triggered by crises in foreign countries in that year. We find that an additional direct crisis exposure reduces bank ROA and ROE by 3 and 31 basis points, respectively, in the same year (direct effect). This base effect goes up by approximately one third for an additional indirect crisis exposure through banks in a crisis country (indirect effect). NIMs are lower by almost 3 basis points for each additional direct crisis exposure. These results control for banks' cross-border exposures to non-banks (firms and sovereigns) and other characteristics, and they are robust to potential endogeneity concerns related to banks' ability to manage their risk exposures.

Next, we examine the effect of crisis exposures on banks' lending decisions and find lower average loan volumes and higher spreads on new corporate loans extended by banks with relatively more crisis exposures. Ten additional direct crisis exposures are associated with a reduction in the average loan share to non-financial firms of 0.8 percentage points. For loan spreads we find a statistically 
significant but small effect. In addition, the impact of direct crisis exposures on both loan volumes and spreads is more pronounced for loans to foreign firms and small firms than it is for loans to domestic or larger firms. These findings complement the existing evidence on bank deleveraging in the face of negative balance-sheet shocks, which highlights heterogenous effects across firms. Banks tend to cut back activity in distant markets before doing so in their home markets (de Haas and van Horen, 2013; Giannetti and Laeven, 2012), leading to stronger credit retrenchment for foreign firms.

After documenting the effects of crisis exposures on bank profitability and loan decisions, we turn to their impacts on the real economy through the lens of firm investment and growth. Real performance is measured using the firm's investment rate and asset growth. We estimate real effects regressions in a firm-year panel and include firm characteristics as well as country $\times$ industry $\times$ year fixed effects to capture shifts in demand. We find that crisis exposures on lender balance sheets have binding effects on borrower firms. In particular, firms which borrow from banks with more direct crisis exposures perform worse than other firms. Consistent with the differential lending effects by firm size, this effect too is more pronounced for smaller firms, consistent with the view that smaller firms are more bank-dependent and hence more sensitive to financial intermediary health and credit conditions (Gertler and Gilchrist, 1994). A back-of-the-envelope calculation suggests that in the absence of lender banks' crisis exposures, the average investment ratio of the firms in our sample would have been higher by 1.7\% during 1997-2012 and 3.9\% during the financial crisis of 2007-2009. The corresponding numbers for firm asset growth are $4.2 \%$ and $9.8 \%$, respectively.

Our study adds to three strands of literature. First, the paper fits into the broad literature on international financial contagion which goes back to the 1990s (Karolyi, 2003; Claessens and Forbes, 2001). Most closely related to our paper are recent studies that highlight the role of global banks in transmitting financial sector shocks to the real economy. Iyer, Peydró, da Rocha-Lopes and Schoar (2014), de Haas and van Horen (2013), Cetorelli and Goldberg (2011), and Ivashina and Scharfstein (2010), among others, trace the impact of liquidity shocks experienced during the 2007-2009 financial crisis. This literature focuses on liability-side shocks stemming from stress in credit markets that impair banks' ability to secure wholesale funding and lend to businesses. Other papers analyze negative shocks to the asset side of banks' balance sheets, which is similar to the approach of our study. For example, Ongena, Tumer-Alkan and von Westernhagen (2016) and Puri, Rocholl and Steffen (2011) show that German banks with higher exposure to U.S. subprime assets retrenched lending operations when U.S. real estate prices started to fall; and de Haas and van Horen 
(2012) find that global banks responded to losses on subprime assets by curtailing foreign lending. ${ }^{3}$ We contribute to this literature by studying, to our knowledge for the first time, shocks to global banks' assets that arise from their lending activities to banks in foreign markets. In addition, we examine not only the direct effects of such exposures, but also their indirect effects. Our approach thus emphasizes the role of financial interconnectedness in the propagation of financial stress from countries in crisis to the real sector in countries that are ex-ante financially healthy. ${ }^{4}$

Second, a closely related literature documents shock transmission among financial firms by emphasizing the effect of exposures to failed firms on creditors' stock market performance. Jorion and Zhang (2009) document "credit contagion," a causal link from announcements of bank bankruptcies to negative equity returns and higher credit default swap spreads for their creditors. Helwege and Zhang (2016) show that distress of a financial firm has negative effects on the market valuations of financial firms with similar characteristics. Both a "counterparty contagion" channel, reflecting direct losses caused by bankruptcy filings, and an "information contagion" channel, reflecting negative externalities from bad news about a particular institution or type of asset, account for these negative valuation effects. However, in their paper the counterparty channel is empirically small and there is no evidence of a cascade of failures, because banks hold diversified portfolios, limiting their exposures to individual counterparties. We bring to this literature an analysis of credit risk exposures among financial institutions in a global context, covering a large sample of banks in 115 countries. The richer diversity of banks and crises enhances the generality of our results. More importantly, we show that the negative externality from contagion goes beyond bank's financial returns and impacts the real economy.

Finally, the real effects of bank lending have been studied in the literature on the transmission of shocks through interbank connections, especially in a domestic context. Cingano, Manaresi and Sette (2016) document that the crunch in the Italian interbank market during the 20072009 financial crisis led banks with large exposures to this market to curtail credit, with negative effects on firm investment, especially for younger and smaller firms. Iyer and Peydró (2011) find contagion effects in the Indian interbank market, showing that after the failure of a large bank, banks exposed to it experience large deposit withdrawals, suffer a loss of profitability and cut back

\footnotetext{
${ }^{3}$ In the context of the European sovereign debt crisis, Popov and van Horen (2015) find that greater exposures to risky foreign sovereign lead to lower bank credit.

${ }^{4}$ It is important to note that we do not examine crisis exposures on the liability side - that is, borrower exposures to creditors in stress. While it is possible that such exposures may translate into funding problems for the borrower banks, they may be able to substitute to other creditors, which would diminish the impact of liability-side shocks. Our tests for crisis transmission through syndicated loan-related liability exposures to crisis banks found no significant effect.
} 
loans, propagating the shock to the real sector. The mechanism by which we expect cross-border crisis exposures to impact bank credit and firm activity is a standard bank lending channel of shock transmission as highlighted in these contributions. However, our paper emphasizes the international dimension of this channel by considering the global market for cross-border (long-term) interbank loans rather than the domestic overnight interbank market. Although our narrative focuses on crisis exposures as a negative shock, our setup flexibly allows us to consider the impact of non-crisis exposures as well. For non-crisis exposures we generally find positive but insignificant effects.

\section{The Cross-Border Interbank Market}

We begin by briefly describing the market for cross-border interbank loans and reviewing some estimates of its size. Interbank lending represents about $10 \%$ of total deal number and volume in the global syndicated loan market (see Figure 1). ${ }^{5}$ The largest lenders in the last two decades were banks in the U.S., U.K., Japan, France, and Germany. Confidential data from the Bank of International Settlements (BIS) gives us an indication of how large cross-border claims created through this particular market are relative to total cross-border interbank claims. Using BIS data on bilateral cross-border positions reported by internationally-active banks, we estimate these exposures to account for almost 30\% during 1997-2012 (see Figure 2). ${ }^{6}$

It is also possible to gauge the importance of cross-border interbank exposures in bank balance sheets. Panel A in Table 1 lists the top 25 lender countries by size of foreign interbank exposures relative to total gross loans. In our sample they represent on average $3.2 \%$ of total loans during 1997-2012. This average, however, conceals a high degree of variation across countries. For instance, cross-border interbank exposures are almost 10\% of U.K. banks' loan portfolios. During 1997-2012, the largest borrower countries in the cross-border interbank market were the U.S., U.K., Australia, and France, and among emerging markets, Brazil, India, the Russian Federation, South Korea, and Turkey. In our matched sample, interbank loans represent $5 \%$ of total liabilities and $8 \%$ of total

\footnotetext{
${ }^{5}$ Syndicated loans are extended by financial institutions organized in lending syndicates, and take the form of credit lines and term loans. They are originated by one or more "lead banks" who sell portions of the loan to other lenders. Most loans are issued in U.S. dollars and have floating interest rate based on the London Interbank Offered Rate (LIBOR). Syndicated loans are generally extended to creditworthy borrowers and are held to maturity, but there is an active secondary market for loans extended to leveraged borrowers (see, for instance, Irani and Meisenzahl (2016)). The syndication process allows banks to diversify their portfolios while meeting counterparty exposure limits. Syndicated loan flows are a strong predictor of total loan flows (Gadanecz and von Kleist, 2002).

${ }^{6}$ This estimate is obtained by comparing interbank loan exposures, from which we remove undrawn portions of credit lines following the methodology of Cerutti, Hale and Minoiu (2015), as well as intra-group transfers, with total cross-border loan exposures from the BIS. The remaining exposures are created through single-lender loans.
} 
liabilities less deposits (Panels B-C in Table 1). We can see that these loans are a more significant source of funding for banks from emerging markets than for advanced economies, representing $12.3 \%$ of non-deposit liabilities for banks in Turkey and as much as $41.2 \%$ for banks in Latvia.

\section{Hypotheses and Empirical Approach}

\subsection{Hypothesis Construction}

We are interested in examining the effects of loan exposures to foreign banks on bank profitability, lending decisions, and the real economy. We focus on two types of direct exposures to foreign banks, crisis and non-crisis exposures, labeled $C$ and $N C$, respectively. Crisis exposures refer to the claims on banks in countries experiencing a banking crisis, and non-crisis exposures are claims on banks in countries not experiencing a crisis. There are four types of indirect second-degree exposures: $C C, C N C, N C C$, and $N C N C$. For example, $N C C$ represents a second-degree crisis exposure through a first-degree non-crisis exposure. Figure 3 provides a visualization of all direct and indirect interbank exposures.

We expect negative balance sheet shocks that occur due to cross-border crisis exposures to have a negative impact on bank earnings, translating into lower net income and returns. This effect may occur directly through valuation effects and write-downs on non-performing exposures, or indirectly, through a loss of other business. We review each potential mechanism in detail.

Valuation effects and write-downs on non-performing loans are two direct ways by which a bank's returns would be affected negatively by crisis exposures. The syndicated loan market notably exhibits lower default rates and higher loan recovery rates than other credit markets. ${ }^{7}$ Financial borrowers in particular have low default probabilities because they can benefit from a public backstop aimed at reducing the risk of contagion from financial shocks. Although bank defaults are rare, they do occur, as illustrated in Figure 4 which plots the number of banks rated by Moody's that experienced defaults on at least one debt instrument during 1997-2012. ${ }^{8}$ In addition to defaults, borrower distress in the syndicated loan market typically leads to renegotiations that result in an amendment to the terms of the loan such as a principal write-down, a lower interest rate, a grace

\footnotetext{
${ }^{7}$ For example, in the aftermath the 2007-2009 financial crisis, loan default rates were only $2 \%$ during $2011-2012$. During the past decades, the default rate for firms rated AAA was $0.38 \%$ and that for firms rated B was $21.76 \%$ (1981-2010). Loan recovery rates were $71 \%$ for syndicated loans compared to $43.5 \%$ for unsecured loans (1989-2009) (Standard and Poor's, 2011).

${ }^{8}$ Conditional on a banking crisis, the probability of observing at least one bank default in the countries where at least one bank is rated by Moody's is $84 \%$.
} 
period, or a lengthening of maturity (Standard and Poor's, 2011). All of these loan restructuring options effectively reduce the cash outlays of the borrower and the present value of the loan for the lender, resulting in lower profit margins. A bank may also experience valuation losses on its securities due to crisis exposures. This would occur if banks placed their syndicated credits in the trading book and marked them to market using secondary market prices. This is more likely to happen for high-yield leveraged loans for which there is an active secondary market. To the extent that these loans are designated as "held for trading," marked-to-market losses and gains would affect bank net income and profitability.

Lending banks' profit margins may also be squeezed because of "information contagion," a mechanism through which crisis exposures may lead to a loss of business and higher funding costs for the bank. The literature highlights the negative effects of corporate borrower distress on creditors' market valuation. Dahiya, Saunders and Srinivasan (2003) show that borrower default or bankruptcy announcements lead to negative abnormal stock market returns for the borrower's main lender. Furthermore, large-scale corporate bankruptcies have repercussions for lending banks' reputation and their ability to syndicate loans in the long run. Gopalan, Nanda and Yerramilli (2011) find that lead banks that experience borrower bankruptcies are less likely to subsequently syndicate loans and to attract participant lenders. These results are suggestive of an indirect effect of nonperforming exposures on lenders through a loss of business, which in turn may put pressure on their profit margins.

Given potential direct losses on crisis exposures and indirect information-related losses, we expect crisis exposures to negatively affect bank performance. As losses erode capital and may raise the bank's cost of funds, we also expect crisis exposures to negatively impact the bank's lending decisions. Finally, this shock should affect the real investment and growth performance of firms that borrow from affected banks, to the extent that those firms are bank-dependent and cannot perfectly substitute to alternative financing sources.

We are also interested in examining the impact of higher-degree ("network") exposures on bank and firm outcomes. In financial systems modelled as networks, shocks to a particular financial firm affect not only directly linked firms, but also indirectly linked firms, through higher-order exposures. In other words, negative shocks can have "cascading" effects through the chain of lending relationships (Allen and Gale, 2000). Therefore, even if a bank's direct exposures do not experience financial stress, there may be spillovers and externalities from downstream financial stress. Our specifications will allow for this possibility by including all exposure terms that capture 
direct and indirect exposures as shown in Figure 3.

As for direct and indirect non-crisis exposures, we are largely agnostic about their effects. These effects could be positive, but small, given that the syndicated lending business is highly competitive and has small profit margins (Gadanecz, 2004; Allen, 1990).

\subsection{Empirical Set-up}

We test our hypotheses in four separate datasets.

Bank Profitability. We estimate the effects of cross-border interbank exposures on bank profitability in a bank-year panel. Let $C r_{j t}$ be a dummy variable that takes value 1 if there is a crisis in the country of bank $j$ in year $t$ and $N C r_{j t}$ a dummy variable that takes value 1 if there is no crisis. Define bank $i$ 's total direct crisis as $C_{i t}=\sum_{j} E_{i j t} C r_{j t}$ and non-crisis exposures as $N C_{i t}=\sum_{j} E_{i j t} N C r_{j t}$, where $E_{i j}$ is a dummy variable taking value 1 for the presence of an exposure of bank $i$ to bank $j$. We estimate the following equation: ${ }^{9}$

$$
Y_{i t}=\alpha_{h t}+X_{i t} \beta_{0}+\lambda_{1} C_{i t}+\mu_{1} N C_{i t}+\varepsilon_{i t}
$$

where $Y_{i t}$ is a measure of profitability, $\alpha_{h t}$ is a set of bank country $\times$ year fixed effects, $X_{i t}$ denotes a $(1 \times \mathrm{K})$ matrix of bank $i$ 's $\mathrm{K}$ characteristics in year $t$, and $C_{i t}$ and $N C_{i t}$ are the total number of crisis and non-crisis exposures of bank $i$ in year $t$. The matrix of bank characteristics $X_{i t}$ includes capital adequacy, balance sheet size (log-total assets), indicator variables for bank type and business model, and exposures to firms and sovereigns (collectively referred to as "non-banks"). The regressions include bank country $\times$ year fixed effects to account for time-varying country-level unobservables which may affect banking industry profits, such as changes in the macroeconomic environment, e.g., banking crises, monetary conditions, financial regulation, and crisis management policies. Given the long time-span of our dataset, comparing banks within the same country and year also allows us to rule out differences in accounting standards across countries and over time. ${ }^{10}$

Our coefficient of interest, representing the impact of direct crisis connections on bank profitability, is $\lambda_{1}$. Given that crisis exposures are expected to have a negative impact on bank returns and profit margins, our hypothesis is $\lambda_{1}<0$. We are agnostic about $\mu_{1}$, which could be positive, but small.

\footnotetext{
${ }^{9}$ See Appendix A-I for details on a shock transmission mechanism that produces this specification.

${ }^{10}$ For instance, several countries adopted International Financial Reporting Standards (IFRS) during the 2000s.
} 
Next, we allow for the possibility of spillover effects from second-degree exposures. In light of the crisis transmission paths discussed in the previous section, the effect of indirect exposures to a crisis country may depend on the crisis state of the intermediate bank, which is one step away from the origin of the shock. Therefore, we separate indirect exposures into four possible paths as shown in Figure 3. Let $C C_{i t}$ be the number of indirect (second-degree) crisis exposures of bank $i$ in year $t$ that are reached through its direct (first-degree) crisis exposures. Let $N C C_{i t}$ be the number of indirect (second-degree) crisis exposures of bank $i$ in year $t$ that are reached through its direct (first-degree) non-crisis exposures (captured by $N C_{i t}$ ). We also define $C N C_{i t}$ and $N C N C_{i t}$ similarly. With this notation for indirect crisis exposures, we then estimate the following equation:

$$
\begin{aligned}
Y_{i t} & =\alpha_{h t}+X_{i t} \beta_{0}+\lambda_{1} C_{i t}+\mu_{1} N C_{i t} \\
& +\lambda_{2} C C_{i t}+\lambda_{3} N C C_{i t}+\mu_{2} C N C_{i t}+\mu_{3} N C N C_{i t}+\varepsilon_{i t}
\end{aligned}
$$

Here, in addition to direct effects, we are also interested in the effects of indirect $C C$ and $C N C$ exposures $\left(\lambda_{2}\right.$ and $\left.\mu_{2}\right)$. Depending on their nature, second-order, downstream connections could amplify or mitigate the effect of first-order exposures. For instance, a direct crisis connection could be further weakened by direct links to other crisis banks, resulting in an amplifying effect on a $C C$ path $\left(\lambda_{2}<0\right)$. The reverse may happen if a crisis connection has direct links to non-crisis banks, resulting in a dampening effect on a $C N C$ path $\left(\mu_{2}>0\right)$. However, as discussed before, the effects of direct and indirect non-crisis exposures are likely to be positive, but small. In our regressions, the coefficients $\lambda_{3}$ and $\mu_{3}$ turn out to be statistically insignificant, therefore in subsequent equations we will sum these indirect exposures into one term $\left(N C C_{i t}+N C N C_{i t}\right)$.

Bank Loan Volumes and Prices. To study the effects of crisis exposures on the quantity and price of loans supplied by banks, we construct two additional datasets. Quantity effects are examined in a loan share-bank-firm-year dataset and pricing effects are tested in a bank-firm-year dataset. We use a specification similar to Equations 1 and 2, but add the borrower dimension to our dataset. The specification is given by:

$$
\begin{aligned}
L_{z i m t} & =\alpha_{t}+\alpha_{i}+X_{i t} \beta_{0}+Z_{z} \beta_{1}+\lambda_{1} C_{i t}+\mu_{1} N C_{i t} \\
& +\lambda_{2} C C_{i t}+\mu_{2} C N C_{i t}+\lambda_{4}\left(N C C_{i t}+N C N C_{i t}\right)+\varepsilon_{z i m t}
\end{aligned}
$$

where $L_{z i m t}$ denotes the individual share of bank $i$ in loan deal $z$ extended to firm $m$ in year $t$, and $\alpha_{i}$ and $\alpha_{t}$ denote bank and year fixed effects. (The results are robust to including bank country $\times$ year fixed effects to absorb all macroeconomic conditions in the bank's home country.) 
In addition to the usual bank characteristics $X_{i t}$, we control for several loan-level characteristics $Z_{z}$ (credit line dummy, loan currency dummies, and the number of syndicate members in the loan deal). We also include a dummy variable for lead banks to allow for the fact that they systematically contribute larger loan amounts than simple participants (Mora, 2015).

The specification in Equation 3 uses an identification strategy similar to Duchin and Sosyura (2014), which is based on controlling for firm-specific loan demand by specifying the dependent variable as a loan share instead of a loan amount. In this approach, the dependent variable is not affected by shocks to a given firm's demand for loans. Instead, identification comes from the variation in loan shares across multiple lenders within the same syndicated loan, akin to introducing loan fixed effects. Any differences in loan shares within the same loan deal can thus be attributed to differences in bank balance sheet characteristics.

We specify a similar regression for loan spreads, in a bank-firm-year panel, with the difference that the dependent variable is the log-transformed weighted average loan spread across all loans extended by a given bank to a given firm in a given year. The weights reflect the relative size of the each loan. In these regressions we include bank and year fixed effects, but the results are further robust to including bank country $\times$ year fixed effects and firm country $\times$ year fixed effects to control for unobserved time-varying macroeconomic conditions in the bank's and firm's country.

Real Effects. We study firm performance in a fourth dataset - a firm-year panel. We denote firm performance as $F_{m t}$ for firm $m$ in year $t$, captured by the investment ratio (capital expenditure divided by lagged assets) and real asset growth. We estimate specifications similar to Equation 3, but we now control for weighted average crisis and non-crisis exposures of all the banks $i$ that lend to firm $m$ in year $t$ :

$$
\begin{aligned}
F_{m t} & =\alpha_{l k t}+W_{m t} \beta_{0}+\lambda_{1} \sum_{i \in \Theta_{t}} s_{i m t} C_{i t}+\mu_{1} \sum_{i \in \Theta_{t}} s_{i m t} N C_{i t} \\
& +\lambda_{2} \sum_{i \in \Theta_{t}} s_{i m t} C C_{i t}+\mu_{2} \sum_{i \in \Theta_{t}} s_{i m t} C N C_{i t}+\lambda_{4} \sum_{i \in \Theta_{t}} s_{i m t}\left(N C C_{i t}+N C N C_{i t}\right)+\varepsilon_{m t}
\end{aligned}
$$

where $\alpha_{l k t}$ is a set of firm country $\times$ industry $\times$ year fixed effects, $W_{m t}$ is a matrix of time-varying firm characteristics, $\Theta_{t}$ is the set of banks that lend to firm $m$ in year $t$, and $s_{\text {imt }}$ is the share of bank $i$ in total loan volume granted by all banks in $\Theta_{t}$ to firm $m$. The regressors of interest are time-varying direct and indirect crisis exposures at the firm level. Here, too, we expect $\lambda_{1}<0$ and $\lambda_{2}<0$.

The real effects regressions are estimated with a demanding set of firm country $\times$ industry $\times$ year 
fixed effects to control for potential demand shifts within narrowly-defined clusters of firms, assuming all firms in a given country, industry, and year, face the same demand shocks. Industry $l$ is based on 1- or 2-digit Standard Industrial Classification (SIC) industry code.

Heterogeneous Effects. In the bank lending and firm performance regressions we allow for differential effects for domestic vs. foreign firms, and for large vs. small firms. Previous studies document a "flight-home" tendency of global banks that experience balance sheet shocks in that they cut bank lending to distant foreign markets before doing so in the domestic market (de Haas and van Horen, 2013; Giannetti and Laeven, 2012). In addition, smaller firms tend to be more bank-dependent and to have less diversified sources of external financing, which makes them more sensitive to bank credit conditions (Cingano, Manaresi and Sette, 2016; Ongena, Peydró, Van Horen and Bank, 2015; Iyer, Peydró, da Rocha-Lopes and Schoar, 2014; Gertler and Gilchrist, 1994). For these reasons, we expect stronger loan contraction and real effects for foreign and smaller firms.

All results are based on the Ordinary Least Squares (OLS) estimator. The standard errors are heteroskedasticity-robust and clustered at the bank level in the profitability and lending regressions, and at the firm level in the real effects regressions.

\subsection{Potential Sources of Endogeneity}

In this section we discuss potential sources of endogeneity and how we try to address them.

Omitted Variables. In the specifications above we interpret the coefficients of interest as capturing the effect of cross-border interbank exposures. Note that a bank's performance is also affected by its exposures to non-bank borrowers such as non-financial firms and sovereigns, as well as exposures through other asset classes, such as securities holdings or derivatives. These other exposures could lead to a bias in our estimates insofar as they are correlated with our cross-border interbank exposures.

We tackle this issue by including the best proxies that are available to us. For cross-border exposures obtained through syndicated loans, we include bank-level control variables for exposures to firms and sovereigns. In regards to cross-border non-syndicated exposures (such as corporate or sovereign bondholdings), direct controls at the bank level are unfortunately not possible because bilateral data on cross-border bondholdings in a global sample of banks are not available. As a proxy, we use aggregate data at the banking-system level from the BIS banking statistics. Controlling for bilateral cross-border positions of the lender's banking system vis-a-vis foreign cor- 
porates and sovereigns leaves all of our results unchanged. ${ }^{11}$ For purposes of the analysis we opt for parsimonious specifications that exclude these additional controls.

Endogenous Network and Measurement Error. Another possibility is that banks recognize that being interconnected carries certain risks and try to form links in ways that mitigate these risks. The result would be an endogenous network in which the banks position themselves in a way that helps reduce the impact of shocks, for example by reducing their exposures in anticipation of foreign market turmoil. We address this issue in detail in Section 5.1.2. It is also possible that banks hedge some of the credit risk in their interbank exposures; for instance, by buying credit default swaps. If credit portfolio management tools such as hedging, loan sales, and securitization are more likely to be employed by larger and more interconnected banks, there may be systematic measurement error in interbank exposures. Note that both endogenous link formation and portfolio management tools would likely reduce the impact of observed crisis exposures on bank outcomes and associated real effects, attenuating our estimates for the impact of crisis exposures.

\section{Data}

The empirical analysis uses the following ingredients: bank-level estimates of cross-border interbank exposures, bank and firm balance sheet data, data on origination of corporate loans, and financial crisis dates. We link loan-, bank- and firm-level datasets in order to analyze the lending behavior of banks with differential exposures to the cross-border interbank market and the real performance of their borrowers. We describe each data source and the main variables below. Summary statistics for all variables used in the regression analysis are reported in Table 2.

Cross-border Interbank Exposures. Bank-level exposures to banks in foreign markets are constructed from data on individual loan deals. These data come from Dealogic's Loan Analytics, a database with extensive international coverage of syndicated loans. To construct interbank exposures for the 1997-2012 period, we obtain information for 170,274 loan deals signed between 1990 and 2012. For each loan we observe the identities of the borrower and lenders, the loan amount in U.S. dollars (which we express at 2005 prices using the U.S. consumer price index), and loan origination and maturity dates. From these data we retain 16,526 interbank loans and construct bank-level foreign exposures among 6,083 banks with cross-border lending and/or borrowing oper-

\footnotetext{
${ }^{11}$ The results including these variables as controls are available upon request.
} 
ations. $^{12}$ An important caveat of this approach is that we only observe loans at origination and do not have information on credit line drawdowns, liquidation, prepayments, side-arrangements, or loan sales made by lenders to reduce or remove these exposures from their balance sheets. Therefore, to limit the well-known problem of possible measurement error in estimated dollar exposures (de Haas and van Horen, 2013; Bord and Santos, 2012; Ivashina, 2009), we conduct the empirical analysis using the number of exposures rather than their dollar value. ${ }^{13}$

Direct and indirect exposures are defined as follows. Direct exposures of bank $i$ in year $t$ represent the number of banks to which bank $i$ has direct exposures in that year. Direct exposures are calculated based on all the loans that were extended by bank $i$ starting in 1990 until and including year $t$ and that are outstanding at the end of year $t .{ }^{14}$ The sum of these exposures is simply a bank's number of direct counterparties. Indirect exposures of bank $i$ in year $t$ are the direct exposures of those banks to which bank $i$ has direct exposures in year $t$. These are two-step away exposures because they represent the number of direct counterparties of a bank's direct counterparties. From the same data source, we use individual loans to non-financial sector borrowers (firms and sovereigns) to construct exposures to non-banks. Since non-bank borrowers are rarely involved in lending themselves, we only compute direct exposures to non-banks and use them as control variables in all our regressions.

The total number of crisis exposures across the banks in our sample $(C, C C$, and $C N C)$ is shown in Figure 5. We can see that there were relatively more direct crisis exposures in the earlier part of the period, notably the 1997-1998 East Asian crisis, and there were relatively more indirect crisis exposures in the latter part of the period, notably the 2007-2009 financial crisis. These figures reflect the growing internationalization of cross-border interbank lending operations.

Bank Balance Sheets. Data on bank balance sheets comes from Bankscope. Due to the lack of common identifiers in Dealogic Loan Analytics and Bankscope, we hand-match each bank in Dealogic with its financial information from Bankscope by name and country (that is, on a locational basis). Prior to the match we process the lender names in Dealogic to account for name changes, mergers, and acquisitions over the sample period. (See Appendix A-II for more details.)

\footnotetext{
${ }^{12}$ See Appendix A-II for details on data construction.

${ }^{13}$ Another reason why we prefer the number of exposures over their dollar value is that while direct dollar exposures reflect the maximum size of losses for a creditor bank, indirect dollar exposures do not have a similar interpretation. As a robustness test we estimate several specifications for bank profitability in which we include direct dollar-value exposures, in logs. We find that larger crisis exposures negatively affect bank outcomes, but the coefficients are less precisely estimated than in the baseline regressions (results available upon request).

${ }^{14}$ We start in 1990 to make sure we have a good measure of exposure in 1997, the first year of our sample period, given that the average loan maturity in the sample is close to 3 years and the standard deviation is also 3.
} 
While we use the full network of 6,083 banks to compute crisis and non-crisis exposures, our final regression sample of matched banks includes 1,869 banks due to the availability of balance sheet information in Bankscope. ${ }^{15}$

For the profitability analysis we use return on assets (ROA), return on equity (ROE), and net interest margins (NIM) as general indicators of bank performance and financial health. ${ }^{16}$ Other bank variables include bank capital (equity/assets), size (log-total assets), dummy variables for bank type (controlled subsidiary, global ultimate owner, and other), and dummy variables for bank business model (commercial banks, investment banks, and other).

Bank Loans. We examine the impact of financial stress in foreign markets on banks' lending decisions using detailed data on corporate loans from Dealogic Loan Analytics. For this purpose, we use 161,270 loans extended by the banks in our sample to financial and non-financial firms over the 1997-2012 period (about 9,000 loans to sovereigns are excluded). ${ }^{17}$ The loan pricing variable ("all-in-spread-drawn") refers to the sum of the spread over the reference rate (mostly the LIBOR) plus the facility fee associated with the granting of the loan. ${ }^{18}$

Firm Performance. Data on firm financials comes from Thomson Reuters Worldscope, a database with balance sheet and income statement information for publicly listed firms around the world. Market capitalization coverage in Worldscope exceeds $90 \%$ for advanced economies and $70 \%$ for emerging markets. Worldscope does not share a common identifier with Dealogic Loan Analytics. Therefore, we perform a string match based on firm name and country, which we double-check to correct any erroneous or ambiguous matches. The regression dataset comprises about 4,300 firms.

Systemic Banking Crises. Data on the incidence of banking crises comes from Laeven and Valencia (2013). The authors define "systemic banking crises" as periods during which the domestic banking system experiences significant stress and at least three of the following six interventions are implemented by public authorities: guarantees on bank liabilities, extensive liquidity support,

\footnotetext{
${ }^{15}$ Note that our analysis is subject to survival bias, as some of the banks experiencing large losses in a period may fail subsequently. Exits of unprofitable banks likely works against our results.

${ }^{16}$ Another dependent variable that is indicative of bank performance is bank stock market returns. Analyzing market valuations would require setting up the analysis at the bank holding company level. Unfortunately, we are unable to carry out such an analysis largely due to data limitations, as reliable information on the historical composition and ownership of international banking groups is not available.

${ }^{17}$ The number of banks is lower in the lending regressions than in the profitability regressions because singletons drop out due to the inclusion of bank fixed effects, as do several banks that only lend to sovereigns.

${ }^{18}$ Sample sizes in the pricing regressions are smaller than in the loan volume regressions due to the limited availability of this variable.
} 
significant asset purchases, public takeovers of financial institutions, large restructurings, and deposit freezes or bank holidays. Systemic banking crises occurred in 47 out of 203 countries during 1997-2012 for a total of 165 crisis-years. The average duration of a crisis is 3.5 years for countries that experience at least one crisis during the period and 0.8 years for the full sample of countries.

\section{Results}

We begin with a regression model for bank profitability based on Equation 2, which relates bank accounting returns to cross-border interbank exposures and bank characteristics. We also estimate a modified specification to account for the potential endogeneity of crisis exposures. Then, we examine the real effects of cross-border crisis exposures with a series of bank lending and firm performance specifications, corresponding to Equations 3 and 4.

\subsection{Crisis Exposures and Bank Profitability}

\subsubsection{Main Findings}

In Table 3 we report the results of our bank profitability regressions, in which the dependent variables are ROA, ROE, and NIMs and the regressors of interest are crisis exposures. We first examine the impact of direct crisis exposures (columns 1, 4, 7). Across specifications, the coefficient estimates indicate that a higher number of direct exposures to banks in countries experiencing systemic banking crises is associated with lower bank profitability. Coefficient estimates on the regressors of interest are statistically significant at conventional levels. In column 1, the estimate -0.029 indicates that adding a new crisis exposures (on top of existing exposures) reduces ROA by 2.9 basis points in the same year or by $3.5 \%$ of mean ROA. To put this number in perspective, for a bank with total assets of one trillion U.S. dollars, ${ }^{19}$ an additional crisis connection translates into a reduction in annual returns of close to 300 million U.S. dollars.

The results are similar when we use ROE or NIMs as measures of bank profitability (columns 4, 7). The estimated coefficients indicate an additional crisis exposure reduces bank ROE by 30 basis points and NIMs by 2.7 basis points for the average bank in the sample. The difference between NIMs of a bank with no crisis exposures and that of the Hong Kong subsidiary of Long-Term Credit Bank of Japan with 40 crisis exposures (in 1998) is 108 basis points (or $39 \%$ of the mean).

\footnotetext{
${ }^{19}$ There were 29 banks with total assets larger than 1 trillion U.S. dollars in 2012, according to data from Bankscope.
} 
In the next set of specifications we add indirect exposures (columns 2, 5, 8), that is, crisis and non-crisis exposures of first-degree counterparty banks. The coefficients on these second-degree exposures are statistically insignificant. However, these measures ignore the network structure of bank connections, where the path of a connection can influence the transmission of shocks along a chain of lending relationships. In Section 3.2 we conjectured that a second-degree crisis exposure could have a significant effect on bank returns if the first-degree exposure were also a crisis exposure (a $C C$ path). To explore this possibility, in the following specifications (columns $3,6,9)$ we condition on the first-degree exposures and include separately all the paths shown in Figure 3. The estimated coefficients confirm that second-degree crisis exposures $(C C)$ negatively correlate with bank profitability. An additional indirect exposure to a crisis country bank through a crisis-country bank $(C C)$ reduces ROA by 0.8 basis points on top of the effect of a crisis exposures $(C)$ (or $34 \%$ of the base effect of $C$ ). By contrast, an additional indirect exposure to a non-crisis country bank $(C N C)$ through a crisis-country bank reduces the negative effect on ROA by 0.4 basis points $(17 \%$ of the base effect of $C$ ). These comprehensive regressions that include both direct and indirect exposures are our preferred specification. ${ }^{20}$

These results suggest that systemic banking crises around the world reduce the profitability of banks with exposures to distressed foreign markets. Cross-border interbank exposures act as a channel of international shock transmission, which means that diversification across financial partners can turn into a vulnerability when the countries where these partners operate experience financial stress. The magnitudes of the estimated impacts are economically meaningful in the context of large and highly leveraged bank balance sheets, which are common in modern financial systems. For such banks, relatively small ROA and ROE movements can imply large dollar losses. ${ }^{21}$

\subsubsection{Potential Shock Anticipation}

As discussed in Section 3.3, the estimates of crisis exposures' impacts may suffer from endogeneity if banks react to anticipated negative shocks from foreign counterparts. Banks may try to limit

\footnotetext{
${ }^{20}$ These results are robust to controlling for the characteristics of counterparty banks in specifications that derive directly from Equation 2, as shown in Appendix Table A1.

${ }^{21}$ In Tables A2-A3 we further refine these bank profitability results. In Table A2 we examine the persistence of the negative effects of cross-border crisis exposures on bank profitability, possibly due to the lags involved in banks recognizing impairments and write-offs on the balance sheet, and find that the baseline impacts persist in outer years. In Table A3 we allow the baseline profitability effects of direct crisis exposures to differ based on bank capital and size, two important determinants of banks' ability to withstand shocks. On balance, the results show that ROA and ROE of relatively smaller and thinly-capitalized banks are most responsive to foreign shocks, while NIMs are more uniformly impacted across bank types.
} 
their exposures to foreign markets in anticipation of negative shocks in those markets, leading to an attenuation of our main estimates. To obtain more precise estimates we would like to disaggregate interbank exposures into components that differ in the ease with which they can be adjusted by the bank.

We decompose an interbank exposure in year $t$ into a "stock" exposure that was in place as of the end of year $t-1$ and a "flow" exposure based on loans originated during year $t$. Banks should have a harder time adjusting their stock exposures than their flow exposures because unwinding existing positions via loan sales requires appropriate market conditions, existence of willing buyers, and may still entail large haircuts, whereas adjusting the loan flow is possible by simply not extending new loans. For this reason, stock exposures should be less contaminated by endogeneity concerns than are flow exposures.

Following this logic, in Table 4 we estimate our preferred specification after replacing the direct crisis exposures with these two components - the "stock" exposures $S$, formed from the loans originated until the end of year $t-1$ and the "flow" exposure $F$ formed solely from the loans originated in year $t$. This approach yields statistically significant results only for stock exposures, as well as quantitatively similar estimates across all specifications (columns 1-6). This supports the idea that financial shocks are transmitted mainly through the portion of exposures that is predetermined and hence hardest to adjust endogenously.

\subsection{Crisis Exposures and Bank Lending: Quantity and Price}

Next we examine the lending effects of exposures to banks in crisis countries. While bank profitability is important in its own right, we take advantage of our detailed loan origination data to go one step further and estimate the loan supply effects of crisis exposures. We look at both loan quantity and pricing effects. We use data on individual loans extended by the banks in our sample to financial and non-financial borrowers during 1997-2012. The data are at the loan share-bankborrower level, representing loan shares contributed by each bank in a syndicated loan deal, and borrowers are individual firms. This data structure is advantageous because it implicitly controls for time-varying shifts in demand at the firm level given that the dependent variable is scaled by total loan amount. For loan pricing regressions we similarly use data on individual loans but aggregate it differently. We construct a panel at the bank-borrower-year level where loan spreads are averaged across multiple loans for any given bank-firm pair (and log-transformed). We run regressions akin to Equation 3 in the full sample and then disaggregate the effect for financial and 
non-financial firms.

As seen in Table 5, the results are largely consistent with those for bank profitability, and indicate that direct crisis exposures are associated with lower loan shares and higher spreads. The coefficient estimates on crisis exposures (-0.069 in column 2) indicates that one additional direct crisis exposure reduces the average loan share by 0.069 percentage points (across all firms). However, this effect is driven by non-financial firms (column 3), for which the coefficient estimate on crisis exposures (-0.083) indicates that an additional direct crisis exposure reduces the average loan share by 0.083 percentage points. The difference between the average loan share of a bank with no crisis exposures and one with 40 direct crisis exposures (such as the Hong Kong subsidiary of Japanese bank Long-Term Credit Bank in 1998) is 3.32 percentage points. In addition, the effect of indirect $C C$ exposures is negative, but imprecisely estimated (columns 2 and 3).

Turning to pricing effects, columns 4-6 show that direct crisis exposures are associated with higher spreads on new corporate loans for the average borrower in the sample. Using the coefficient estimates in column 5, an additional direct crisis exposure increases the spread by $0.11 \%$. This effect, although small, is amplified by second-degree crisis exposures: one indirect crisis exposure $(C C)$ on top of the existing direct exposures further increases the spread by $36 \%$ of the base effect (or $0.04 \%$ ). The difference between the loan spreads of a bank with no crisis exposures and one with 40 direct crisis exposures and 252 indirect crisis exposures (such as the Hong Kong subsidiary of Japanese bank Long-Term Credit Bank in 1998) is close to 15\%. Loan pricing thus responds not only to direct crisis exposures, but also indirect ones, consistent with the bank profitability results. In column 6 we see that the full-sample effect of direct crisis exposures is driven by loans to non-financial firms, similar to the loan volume results.

The pricing regressions in columns 4-6 reveal several additional results. First, a higher number of non-crisis exposures - both direct and indirect - is systematically associated with lower spreads. Second, direct exposures to non-banks matter for loan spreads, and the coefficients have the expected signs and are statistically significant. Notice also that the coefficients on indirect non-crisis exposures $(N C C+N C N C)$ are statistically significant, suggesting non-crisis exposures are associated with a decrease in loan spreads.

In Table 6 we look for differential effects by firm location and size by breaking up the main coefficient of interest on direct crisis exposures by firm type. ${ }^{22}$ The sample is limited to non-

\footnotetext{
${ }^{22}$ To preserve sample size, these regressions are run for all firms (not only firms that are matched with financial information), and firm size is proxied by average loan amount to a given firm over the full sample period. In the matched sample, firm size measured this way and firm size measured based on total assets have a correlation of 0.40 .
} 
financial firms. In columns 1 and 4 we document a negative effect of banks' direct crisis exposures on loan characteristics solely for loans to foreign firms. In columns 2 and 5 the same negative effect is statistically significant only for small firms (with below-median average loan size). Columns 3 and 6 allow for richer heterogeneity across firm types with a four-variable decomposition which exploits variation across both firm location and size. The results indicate that in the face of foreign shocks, the average bank reduces loan shares and raises spreads the most on new loans granted to small and foreign firms. Notice also that across specifications the coefficients on indirect crisis exposures $(C C)$ take the expected sign and, for loan spreads, they are also statistically significant (columns 4-6).

So far we have shown that crisis exposures are associated with worse credit terms for all firms that borrow from crisis-exposed banks. This effect could be further decomposed into a credit crunch for the firms in the country that is the origin of the shock (A), the firms in the country of the exposed banks ("domestic firms," in B), and the firms that are located in other, ex-ante healthy, countries ("foreign firms," in C). To investigate the extent to which banks transmit shocks from a crisis origin country (A) to third countries (C), we re-estimate the regressions in Table 6 after excluding bankfirm pairs for which firms are located in crisis origin countries (A). Table 7 reports the results. We find that direct crisis exposures are associated with tighter credit-lower loan volume and higher spread-for firms in foreign countries excluding the origin of the shock. Put differently, banks in country B that are exposed to banks in crisis country A curtail their credit to firms in all other foreign countries $\mathrm{C}$, including those that do not have any direct exposure to country A. Overall, these results highlight the transmission of financial sector shocks across borders through interbank exposures, even to countries not experiencing banking crises themselves.

\subsection{Crisis Exposures and Firm Performance}

Next we turn to documenting the real effects of systemic banking crises through international bank connections. Here, we quantify the impact of crises in foreign countries on the performance of nonfinancial firms that borrow from the banks with exposures to those countries. We estimate reducedform regressions in a firm-level panel for 1997-2012 and two outcome variables: the investment ratio and total asset growth. We control for firm-level Tobin's $q$ (total market capitalization divided by total asset book value) to capture firms' investment opportunities, size (log-total book assets), and cash flow (in \% of assets). For each firm, bank characteristics (including all types of cross-border exposures) are computed as weighted averages of the firms' lender characteristics, with weights 
given by the share of lending granted by each lender. All regressors are lagged one year. To control for demand as precisely as possible, in addition to Tobin's $q$ we include firm country $\times$ industry $\times$ year fixed effects, where industry is defined as 1- or 2-digit SIC industry classifications.

The results are reported in Tables 8-9 for investment and asset growth, respectively. Among firm level controls, Tobin's $q$ and firm size have intuitive and statistically significant coefficients in all specifications. In column 1 of Table 8, we can see that firms that borrow from banks with a greater number of crisis exposures have lower investment ratios. Columns 2-4 show that this effect is stronger for small firms (with below-median total assets) (at least at the $20 \%$ level) and columns 3-4 show that it is robust to different levels of granularity for our demand controls. The coefficients on other types of exposures are imprecisely estimated. The results are similar for asset growth.

The estimates in Tables 8-9 are also economically sizeable. Based on the coefficients in column 1 of each table, we have that a firm whose average lender acquires 10 additional direct crisis exposures has an investment ratio that is lower by 0.22 percentage points and an average asset growth rate that is lower by 1.1 percentage points. A back-of-the-envelope calculation can tell us the yearly investment and growth that are foregone due to transmission of systemic banking crises through the specific channel of cross-border interbank connections. Using the estimates in column 1, we find that in the absence of lender banks' crisis exposures, the corporate investment ratio in our sample would be higher by $1.7 \%$ and firm balance sheet growth would be higher by $4.2 \%$ during $1997-2012 .^{23}$

These results echo the findings of previous studies that balance sheet shocks to financial intermediaries have binding effects on firm performance, especially for smaller firms that arguably have less diversified sources of external funding (see, among others, Chava and Purnanandam (2011)). They also suggest that even the firms with access to the syndicated loan market are not able to completely make up for a deterioration in bank credit terms by substituting with alternative funding sources. Moreover, we find that by reducing lending to foreign borrowers, banks act as channels of credit crunch transmission across borders.

\footnotetext{
${ }^{23}$ We obtain $1.7 \%$ for the investment ratio using the following figures - coefficient estimate of 0.0216 from column 1 of Table 8 , average direct crisis exposure of 5.38 in the firm-year dataset, and average investment ratio over the sample period of 6.816 . Specifically, $(-0.0216 \times 5.38) / 6.816=-0.017$.
} 


\subsection{Falsification Tests}

Finally, we run falsification tests to make sure the baseline results are not driven by pre-existing trends in bank profitability or by spurious shocks and network connections.

Ruling Out Prior Trends. The first placebo test aims at ruling out the possibility that our results on the transmission of financial shocks through the cross-border interbank connections are due to the banking network itself rather than pre-existing trends in bank profitability. In this test we replace the bank profitability variables with their lags for 2, 4, and 6 years prior to the shock. The results, shown in Panel A of Table 10, reveal that none of the estimates on direct and indirect crisis exposures are consistently significant at the conventional levels in these specifications. Put differently, there is no evidence that prior trends in bank profitability spuriously produce our results.

Capturing Real Shocks and Real Interbank Linkages. A second set of placebo tests addresses the possible concerns that the results are driven by spurious events rather than systemic banking crises and by spurious interbank linkages rather than real cross-border loan exposures. Here we employ three approaches.

First, we randomize the crisis dates across countries in any given year. That is, in each year we randomly assign false crises to banks, keeping the number of false crises equal to the number of real crises within the year. Keeping the set of interbank connections unchanged, we then recalculate crisis and non-crisis exposures and re-run the main specifications. In a second exercise, we change only the set of interbank connections. For this purpose, for each year of our sample we randomly re-assign banks' cross-border interbank connections and once gain re-calculate crisis and non-crisis exposures. This falsification test assumes the banking crisis shocks are real but addresses the concern that network data may contain mismeasured values or false bank connections that produce spurious results. In a third exercise, we allow both interbank connections (network structure) and shocks to change. For this purpose we keep the distribution of crisis and non-crisis exposures fixed within the year but randomly re-assign the exposures across banks.

The results of the placebo tests, for the main coefficients of interest (on $C$ and $C C$ exposures to banks) are reported in Panel B of Table 10. They indicate that randomly reassigning shocks, interbank connections, or both, yields statistically insignificant effects on bank profitability. These results increase our confidence that the baseline findings capture the effects of systemic banking crises on bank profitability, lending decisions, and associated real effects, rather than spurious 
correlation between these events and outcomes of interest.

\section{Conclusions}

The real effects of interbank networks remain understudied, especially in the international context. In this paper we assemble novel data to study the international transmission of financial sector shocks through cross-border interbank lending activities. We construct cross-border interbank exposures for more than 6,000 banks during 1997-2012, which allows us to map global interbank connections and contribute to the existing literature as follows. We examine the effects of direct and indirect bank exposures to foreign markets in turmoil. Specifically, we trace the cross-border transmission of financial shocks to a comprehensive set of outcome variables: bank profitability, bank lending decisions (volumes and prices), and the performance of borrower firms.

We find that a larger number of direct "crisis exposures" reduce banks' accounting returns and profit margins. Affected banks cut back the volume of new corporate loans and charge higher rates on newly granted loans, especially to foreign and small firms. Direct crisis exposures have economically meaningful impacts. On top of the direct negative effect of crisis exposures, indirect (second-degree) crisis exposures have an additional negative impact on bank profitability and lending. The indirect impact is significantly smaller than the direct impact. Furthermore, there are spillovers of first-order crisis exposures to the real sector, even in countries that are not experiencing banking crises themselves.

Our results suggest that banks are unable to fully shield their balance sheets from foreign banking crises and hence may be interpreted as evidence of market incompleteness. Furthermore, they illustrate how interactions in the cross-border interbank market affect bank profitability and the flow of credit in the global economy. Our findings support the notion that interconnected financial systems enable shock transmission across borders through banks, with negative consequences for the real economy. These costs should be weighed against benefits from risk-sharing and greater efficiency of capital allocation due to cross-border expansion of bank activities. These results can also inform the public policy debate on the regulation of global and interconnected banks. 


\section{References}

Acemoglu, D., Carvalho, V. M., Ozdaglar, A. and Tahbaz-Salehi, A. (2012). The network origins of aggregate fluctuations. Econometrica, 80 (5), 1977-2016.

Allen, F. and Gale, D. (2000). Financial contagion. Journal of Political Economy, 108(1), 1-33.

Allen, T. (1990). Developments in the international syndicated loan market in the 1980s. Bank of England Quarterly Bulletin, 30 (1), 71-7.

Bernanke, B. S. (2007). The financial accelerator and the credit channel. Speech delivered at The Credit Channel of Monetary Policy in the Twenty-first Century Conference, Federal Reserve Bank of Atlanta, GA, June 15, $200 \%$.

- (2013). Monitoring the financial system. Speech delivered at the 49th Annual Conference on Bank Structure and Competition, Chicago, IL, May 10, 2013.

—, Gertler, M. and Gilchrist, S. (1999). The financial accelerator in a quantitative business cycle framework. Handbook of Macroeconomics, 1, 1341-1393.

Bord, V. and SAntos, J. A. (2012). The rise of the originate-to-distribute model and the role of banks in financial intermediation. Economic Policy Review, 18 (2), 21-34.

Carvalho, V. M., Nirei, M., Saito, Y. U. and Tahbaz-Salehi, A. (2016). Supply chain disruptions: Evidence from the Great East Japan earthquake. Mimeo.

Cerutti, E., Hale, G. and Minoiu, C. (2015). Financial crises and the composition of crossborder lending. Journal of International Money and Finance, 52, 60-81.

Cetorelli, N. and Goldberg, L. (2011). Global banks and international shock transmission: Evidence from the crisis. IMF Economic Review, 59, 41-76.

Chava, S. and Purnanandam, A. (2011). The effect of banking crisis on bank-dependent borrowers. Journal of Financial Economics, 99 (1), 116-135.

Cingano, F., Manaresi, F. and Sette, E. (2016). Does credit crunch investment down? New evidence on the real effects of the bank-lending channel. Review of Financial Studies, 29, 27372773 .

Claessens, S. and Forbes, K. (2001). International financial contagion. Springer Science \& Business Media. 
Dahiya, S., Saunders, A. and Srinivasan, A. (2003). Financial distress and bank lending relationships. Journal of Finance, 58 (1), 375-399.

DE HAAs, R. and van Horen, N. (2012). International shock transmission after the lehman brothers collapse: Evidence from syndicated lending. American Economic Review, Papers and Proceedings, 102(3), 231-237.

— and - (2013). Running for the exit? international bank lending during a financial crisis. Review of Financial Studies, 26(1), 244-285.

Demsetz, R. S., Saidenberg, M. R. and Strahan, P. E. (1996). Banks with something to lose: The disciplinary role of franchise value. FRBNY Economic Policy Review, 2, 1-14.

Duchin, R. and SosyurA, D. (2014). Safer ratios, riskier portfolios: Banks' response to government aid. Journal of Financial Economics, 113, 1-28.

Dudley, W. C. (2012). Solving the too big to fail problem. Remarks at the Clearing House's Second Annual Business Meeting and Conference, New York City, November 12, 2012.

Gadanecz, B. (2004). The syndicated loan market: structure, development and implications. BIS Quarterly Review, December, 75-89.

— and von Kleist, K. (2002). Do syndicated credits anticipate bis consolidated banking data? BIS Quarterly Review, March, 65-75.

Gertler, M. and Gilchrist, S. (1994). Monetary policy, business cycles and the behavior of small scale firms. Quarterly Journal of Economics, 109 (2), 309-340.

Giannetti, M. and Laeven, L. (2012). The flight home effect: Evidence from the syndicated loan market during financial crises. Journal of Financial Economics, 104(1), 23-43.

Gopalan, R., Nanda, V. and Yerramilli, V. (2011). Does poor performance damage the reputation of financial intermediaries? Evidence from the loan syndication market. Journal of Finance, 66 (6), 2083-2120.

Helwege, J. and Zhang, G. (2016). Financial firm bankruptcy and contagion. Review of Finance, 20 (4), 1321-1362.

IMF (2016). Financial Stability Challenges in a Low-Growth, Low-Rate Era. Policy paper, International Monetary Fund, Washington DC. 
Irani, R. M. and Meisenzahl, R. R. (2016). Loan Sales and Bank Liquidity Management: Evidence from a U.S. Credit Register. Review of Financial Studies, forthcoming.

Ivashina, V. (2009). Asymmetric information effects on loan spreads. Journal of Financial Economics, 92 (2), 300-319.

— and Scharfstein, D. S. (2010). Bank lending during the financial crisis of 2008. Journal of Financial Economics, 97 (3), 319-338.

Iyer, R. and Peydró, J.-L. (2011). Interbank contagion at work: Evidence from a natural experiment. Review of Financial Studies, 24 (4), 1337-1377.

—, Peydró, J.-L., da Rocha-Lopes, S. and Schoar, A. (2014). Interbank liquidity crunch an the firm credit crunch: Evidence from the 2007-2009 crisis. Review of Economic Studies, 27, $347-372$.

Jorion, P. and Zhang, G. (2009). Credit contagion from counterparty risk. Journal of Finance, 64 (5), 2053-2087.

Kapan, T. and Minoiu, C. (2013). Balance sheet strength and bank lending during the global financial crisis. IMF Working Paper No. 13/102.

Karolyi, G. A. (2003). Does international financial contagion really exist? International Finance, $6(2), 179-199$.

Keeley, M. C. (1990). Deposit insurance, risk, and market power in banking. American Economic Review, 80, 1183-1200.

Laeven, L. and Valencia, F. (2013). Systemic banking crises database. IMF Economic Review, 61, 225-270.

MorA, N. (2015). Lender exposure and effort in the syndicated loan market. Journal of Risk and Insurance, 82 (1), 205-252.

Ongena, S., Peydró, J.-L., Van Horen, N. and Bank, D. N. (2015). Shocks abroad, pain at home? Bank-firm level evidence on financial contagion during the recent financial crisis. IMF Economic Review, 63 (4), 698-750.

-, Tumer-Alkan, G. and von Westernhagen, N. (2016). Do exposures to sagging real estate, subprime or conduits abroad lead to contraction and flight to quality in bank lending at home? Deutsche Bundesbank Discussion Paper No. 09/2015. 
Popov, A. and van Horen, N. (2015). Exporting sovereign stress: Evidence from syndicated bank lending during the euro area sovereign debt crisis. Review of Finance, 19 (5), 1825-1866.

Puri, M., Rocholl, J. and Steffen, S. (2011). Global retail lending in the aftermath of the U.S. financial crisis: Distinguishing between supply and demand effects. Journal of Financial Economics, 100 (3), 556-578.

Standard and Poor's (2011). A guide to the loan market. Tech. rep., Standard and Poors Financial Services LLC. Available on https://www.lcdcomps.com/d/pdf/LoanMarketguide.pdf.

Sufi, A. (2007). Information asymmetry and financing arrangements: Evidence from syndicated loans. Journal of Finance, 62 (2), 629-668.

Tumpel-Gugerell, G. (2009). Introductory remarks. Speech at ECB Workshop on recent advances in modeling systemic risk using network analysis, Frankfurt, October 5, 2009.

Wu, D. A. (2017). Shock spillover and financial response in supply chain networks: Evidence from firm-level data. Mimeo. 


\section{Figures and tables}

Figure 1: Size of the Cross-border Interbank Market, 1997-2012

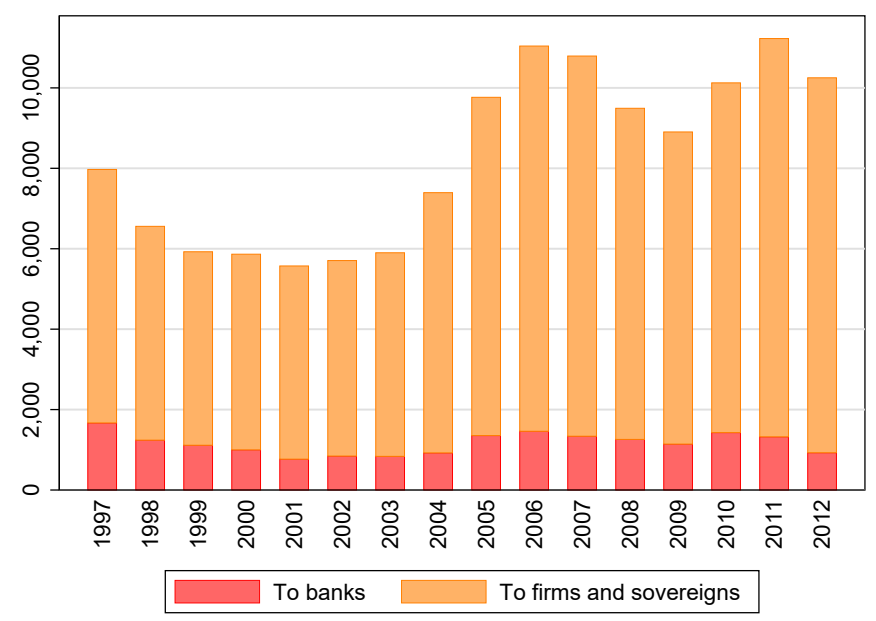

Notes: The figure plots the number of syndicated loans issued to bank and non-bank (corporate and sovereign) borrowers during 1997-2012. Data sources: Dealogic Loan Analytics.

Figure 2: Size of cross-border interbank loan claims, 1997-2012

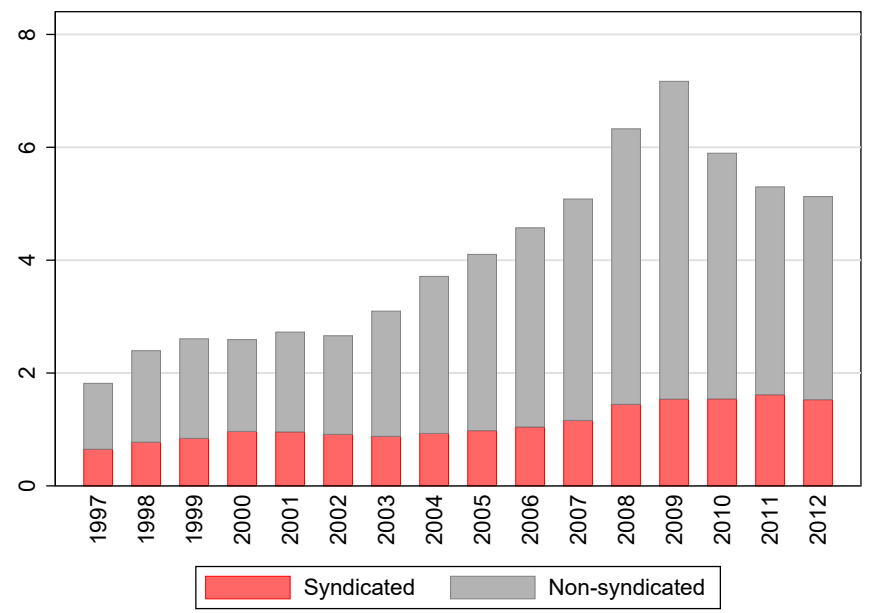

Notes: The figure depicts the composition of cross-border interbank exposures (in trillions of U.S. dollars at 2005 prices), emphasizing claims that are formed through syndicated loans and claims that are formed through nonsyndicated (i.e. single-lender) loans. Claims that are formed through transactions within the same banking group are excluded. The figure is constructed using data on cross-border claims of 35 BIS reporting banking systems vis-a-vis 197 banking systems. Syndicated loan claims are estimated using the methodology in Cerutti, Hale and Minoiu (2015). Data sources: BIS locational banking statistics and Dealogic Loan Analytics. 
Figure 3: Visualization of Direct and Indirect Exposures

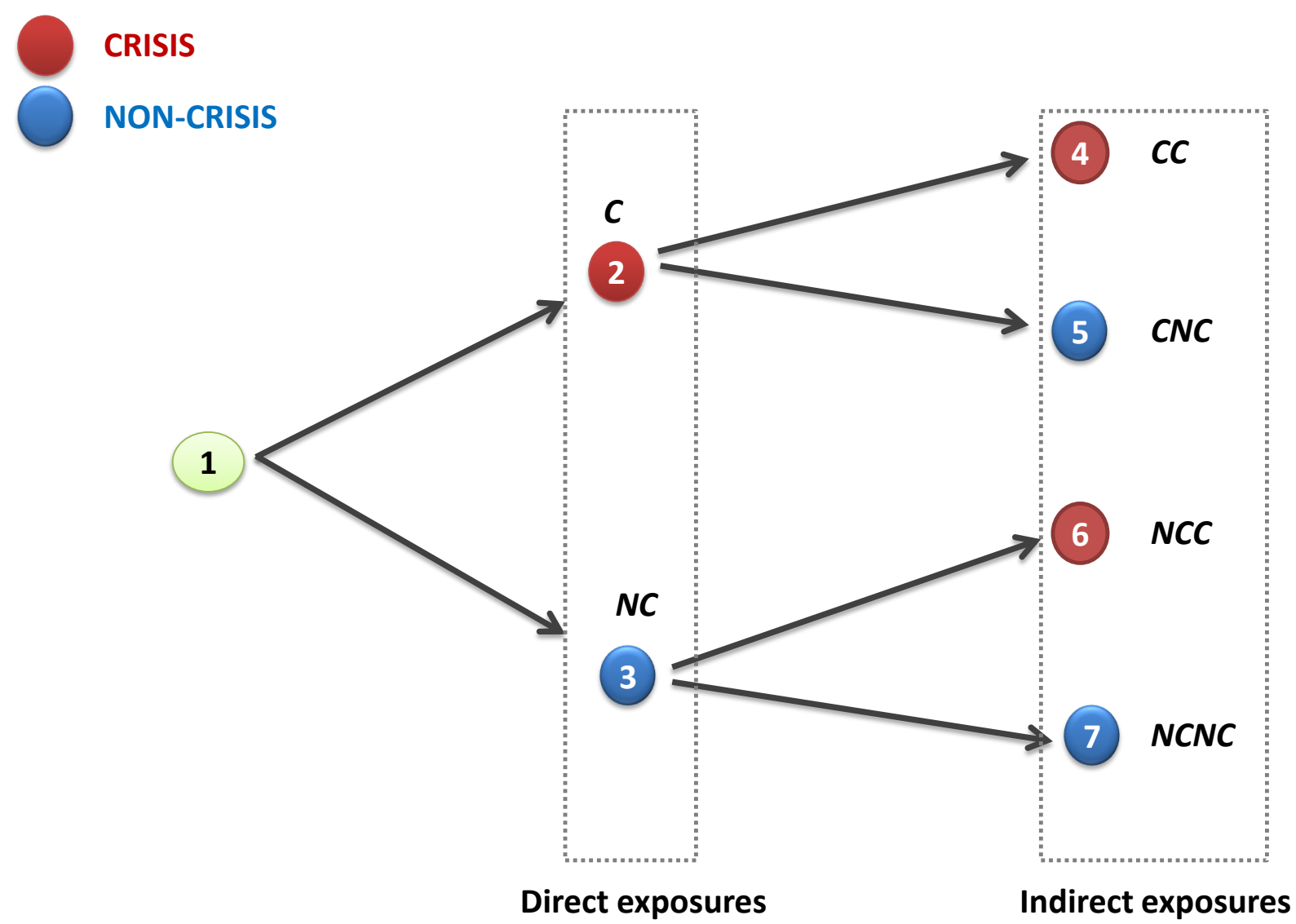

Notes: The figure illustrates direct (first-order or one step away) and indirect (second-order or two steps away) exposures. Throughout the paper and in regression tables, direct exposures are labeled as $C$ (crisis exposures) or $N C$ (non-crisis exposures). Indirect exposures are labeled as $C C$ (crisis exposures through crises), $C N C$ (non-crisis exposures through crises), $N C C$ (crisis exposures through non-crises), and $N C N C$ (non-crisis exposures through non-crises). 
Figure 4: Systemic banking crises and defaulting banks, 1997-2012

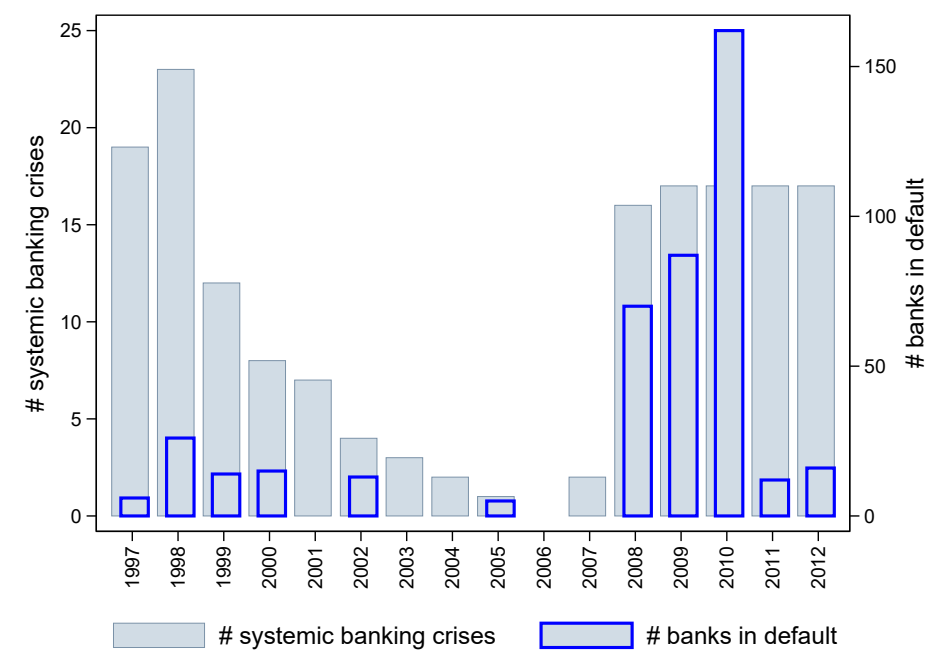

Notes: The figure plots the number of systemic banking crises and the number of defaulting banks (among the population of banks rated by Moody's) on at least one debt instrument during 1997-2012. Data sources: Laeven and Valencia (2013), Moody's Default and Recovery (DRD) database.

Figure 5: Direct and indirect crisis exposures, 1997-2012

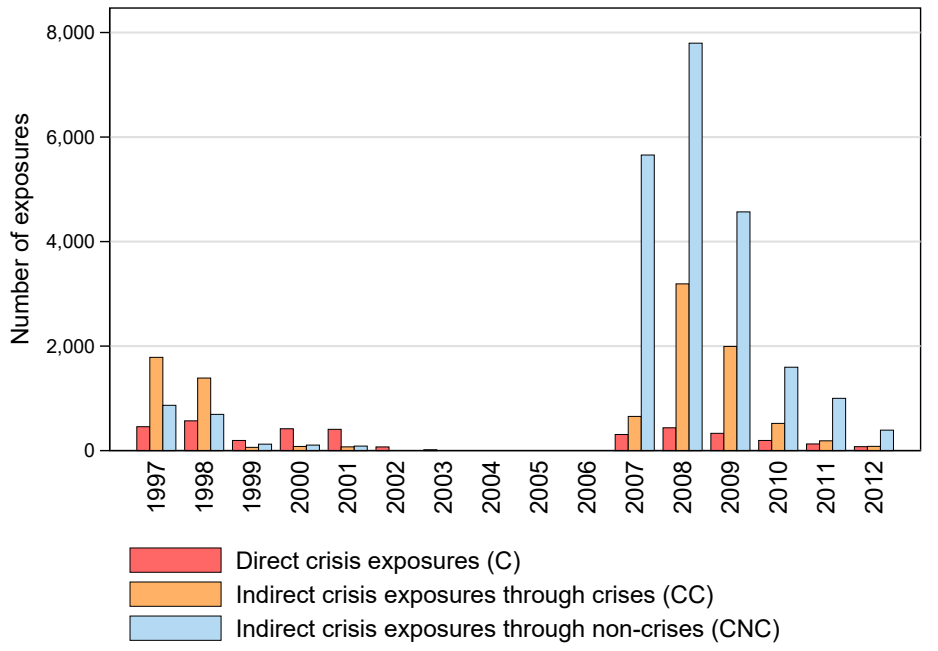

Notes: The figure depicts the number of direct crisis exposures $(C)$, indirect crisis exposures through crises $(C C)$, and indirect non-crisis exposures through crises $(C N C)$ in the regression sample. Data sources: Bankscope, Dealogic Loan Analytics, Laeven and Valencia (2013). 
Table 1: Cross-border Interbank Exposures on Bank Balance Sheets

\begin{tabular}{|c|c|c|c|c|c|}
\hline \multirow{2}{*}{\multicolumn{2}{|c|}{$\begin{array}{l}\text { For lender banks } \\
\text { A. \% gross loans }\end{array}$}} & \multicolumn{4}{|c|}{ For borrower banks } \\
\hline & & \multicolumn{2}{|c|}{ B. $\%$ total liabilities } & \multicolumn{2}{|c|}{ C. \% (total liabilities - deposits) } \\
\hline Malta & 15.4 & Iceland & 12.2 & Latvia & 41.2 \\
\hline Luxembourg & 9.9 & Kazakhstan & 9.5 & Azerbaijan & 25.2 \\
\hline United Kingdom & 8.6 & Azerbaijan & 9.2 & Slovenia & 22.5 \\
\hline Netherlands & 5.9 & Slovenia & 7.9 & Iceland & 20.4 \\
\hline Singapore & 5.3 & Georgia & 7.3 & Malta & 18.7 \\
\hline Belgium & 5.3 & Latvia & 6.6 & Kazakhstan & 15.3 \\
\hline Ireland & 5.0 & Turkey & 6.3 & Turkey & 12.3 \\
\hline France & 4.0 & Algeria & 5.9 & Croatia & 11.7 \\
\hline Hong Kong & 3.7 & El Salvador & 5.1 & Algeria & 10.2 \\
\hline Germany & 3.6 & Norway & 5.0 & Oman & 10.2 \\
\hline Libya & 3.1 & Denmark & 5.0 & Mauritius & 10.0 \\
\hline Switzerland & 3.1 & Croatia & 4.4 & Denmark & 9.5 \\
\hline Bahrain & 2.9 & Ukraine & 4.0 & Hungary & 9.4 \\
\hline Australia & 2.5 & Bahrain & 4.0 & Bulgaria & 9.3 \\
\hline Kuwait & 2.2 & Hungary & 3.9 & Norway & 8.6 \\
\hline Egypt & 2.2 & Oman & 3.3 & Sri Lanka & 8.2 \\
\hline Cyprus & 1.9 & Ireland & 3.2 & Australia & 7.5 \\
\hline Portugal & 1.8 & South Korea & 3.2 & Bahrain & 7.3 \\
\hline Canada & 1.8 & Estonia & 2.9 & Romania & 7.2 \\
\hline Qatar & 1.8 & Argentina & 2.8 & Estonia & 7.1 \\
\hline United Arab Emirates & 1.5 & Russia & 2.6 & Hong Kong & 7.1 \\
\hline Saudi Arabia & 1.4 & Hong Kong & 2.5 & Argentina & 6.7 \\
\hline Argentina & 1.1 & Romania & 2.5 & United Arab Emirates & 6.6 \\
\hline Oman & 1.1 & Australia & 2.4 & Ukraine & 6.5 \\
\hline Italy & 1.0 & Bulgaria & 2.3 & Namibia & 6.4 \\
\hline Top 25 average & 3.8 & Top 25 average & 5.0 & Top 25 average & 12.2 \\
\hline Full sample average & 3.2 & Full sample average & 3.2 & Full sample average & 8.0 \\
\hline
\end{tabular}

Notes: The table reports the top 25 countries by average share of cross-border interbank exposures in total gross loans (Panel A), share of cross-border interbank liabilities in total liabilities (Panel B), and share of cross-border interbank liabilities in total liabilities less deposits (Panel C), during 1997-2012. The full sample average refers to the 50 countries for which bank-level data on cross-border interbank liabilities and total liabilities are available for at least 5 observations. Data sources: Dealogic Loan Analytics and Bankscope. 
Table 2: Descriptive Statistics for Selected Variables

\begin{tabular}{|c|c|c|c|c|c|}
\hline & $\mathrm{N}$ & Mean & St. Dev. & Min & Max \\
\hline \multicolumn{6}{|l|}{ BANK VARIABLES } \\
\hline Return on assets (ROA) & 14,448 & 0.809 & 1.560 & -6.850 & 8.850 \\
\hline Return on equity (ROE) & 14,445 & 8.398 & 16.44 & -78.09 & 53.17 \\
\hline Net interest margins (NIM) & 14,315 & 2.759 & 2.238 & -0.910 & 15.87 \\
\hline Equity/Assets & 14,448 & 8.753 & 9.333 & 0.320 & 81.51 \\
\hline Assets (USD bn) & 14,448 & 72.34 & 236.4 & 0.450 & 3,808 \\
\hline \multicolumn{6}{|l|}{ Busines model: } \\
\hline 1: Commercial bank & 14,448 & 0.808 & 0.394 & 0 & 1 \\
\hline 1: Investment bank & 14,448 & 0.0697 & 0.255 & 0 & 1 \\
\hline 1: Other & 14,448 & 0.122 & 0.327 & 0 & 1 \\
\hline \multicolumn{6}{|l|}{ Entity type: } \\
\hline 1: Subsidiary & 14,448 & 0.507 & 0.500 & 0 & 1 \\
\hline 1: Global ultimate owner & 14,448 & 0.304 & 0.460 & 0 & 1 \\
\hline 1: Other & 14,448 & 0.188 & 0.391 & 0 & 1 \\
\hline \# direct crisis exp. to non-banks & 14,448 & 1.968 & 19.32 & 0 & 582 \\
\hline \# direct non-crisis exp. to non-banks & 14,448 & 5.308 & 29.89 & 0 & 828 \\
\hline Systemic banking crisis (in bank's country) & 14,448 & 0.209 & 0.407 & 0 & 1 \\
\hline \multicolumn{6}{|l|}{ CROSS-BORDER INTERBANK EXPOSURES } \\
\hline \# direct exp. & 14,448 & 4.339 & 13.84 & 0 & 191 \\
\hline \# direct crisis exp. $(C)$ & 14,448 & 0.251 & 1.553 & 0 & 40 \\
\hline$\#$ direct non-crisis exp. $(N C)$ & 14,448 & 4.083 & 13.20 & 0 & 190 \\
\hline \# indirect exp. & 14,448 & 15.62 & 68.19 & 0 & 1,981 \\
\hline \# indirect crisis exp. & 14,448 & 1.611 & 10.64 & 0 & 500 \\
\hline \# indirect non-crisis exp. & 14,448 & 14.01 & 61.37 & 0 & 1,481 \\
\hline \# indirect crisis exp. through crises $(C C)$ & 14,448 & 0.694 & 7.237 & 0 & 415 \\
\hline \# indirect non-crisis exp. through crises $(C N C)$ & 14,448 & 1.585 & 17.25 & 0 & 938 \\
\hline \# indirect crisis exp. through non-crises $(N C C)$ & 14,448 & 0.917 & 5.285 & 0 & 126 \\
\hline \# indirect non-crisis exp. through non-crises $(N C N C)$ & 14,448 & 12.43 & 52.49 & 0 & 1,249 \\
\hline \multicolumn{6}{|l|}{ FIRM VARIABLES } \\
\hline Investment rate (capex/lagged assets) & 10,151 & 6.816 & 6.831 & 0.00 & 28.39 \\
\hline Asset growth rate & 10,149 & 14.33 & 30.25 & -77.43 & 128.74 \\
\hline Tobin's Q & 10,151 & 128.8 & 88.2 & 18.13 & 590.23 \\
\hline Cash flow-to-assets & 10,151 & 8.440 & 9.187 & 0.00 & 99.93 \\
\hline Assets (USD billion) & 10,149 & 8.909 & 24.506 & 0.02 & 751.20 \\
\hline \multicolumn{6}{|l|}{ LOAN-LEVEL VARIABLES } \\
\hline Loan share (all banks) & 319,267 & 17.31 & 19.42 & 0 & 100 \\
\hline 1: Credit line & 319,267 & 0.614 & 0.487 & 0 & 1 \\
\hline \# lenders in syndicate & 319,267 & 12.08 & 10.35 & 1 & 118 \\
\hline 1: Domestic firm & 319,267 & 0.60 & 0.49 & 0 & 1 \\
\hline Loan spread & 134,461 & 170.6 & 125.0 & 12.50 & 750 \\
\hline $\log ($ loan spread $)$ & 134,461 & 4.836 & 0.845 & 2.53 & 6.62 \\
\hline
\end{tabular}

Notes: The table reports summary statistics for selected regression variables. "Commercial banks" category includes cooperative banks, saving banks, real estate and mortgage banks, and other credit institutions. "Other" business model category includes bank holding companies, finance companies, investment and trust corporations, securities firms, private banking and asset management companies, and group finance companies. Bank entity type "other" category includes branch locations, independent companies, and single location banks. Except cross-border interbank exposures, all bank and firm variables are winsorized at the 1st and 99th percentiles of their distributions. Data sources: Dealogic Loan Analytics, Bankscope, Worldscope, and Laeven and Valencia (2013). 


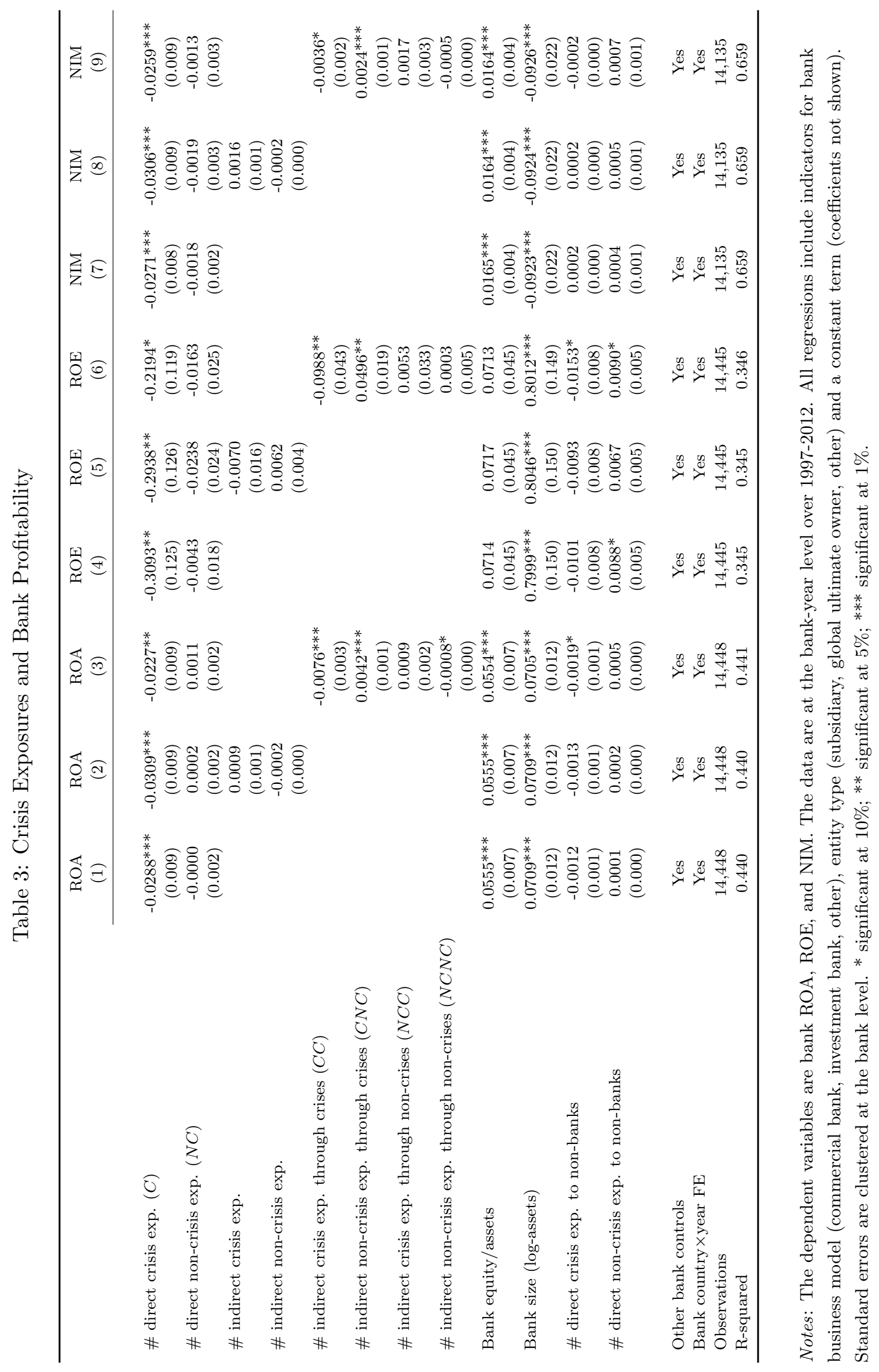




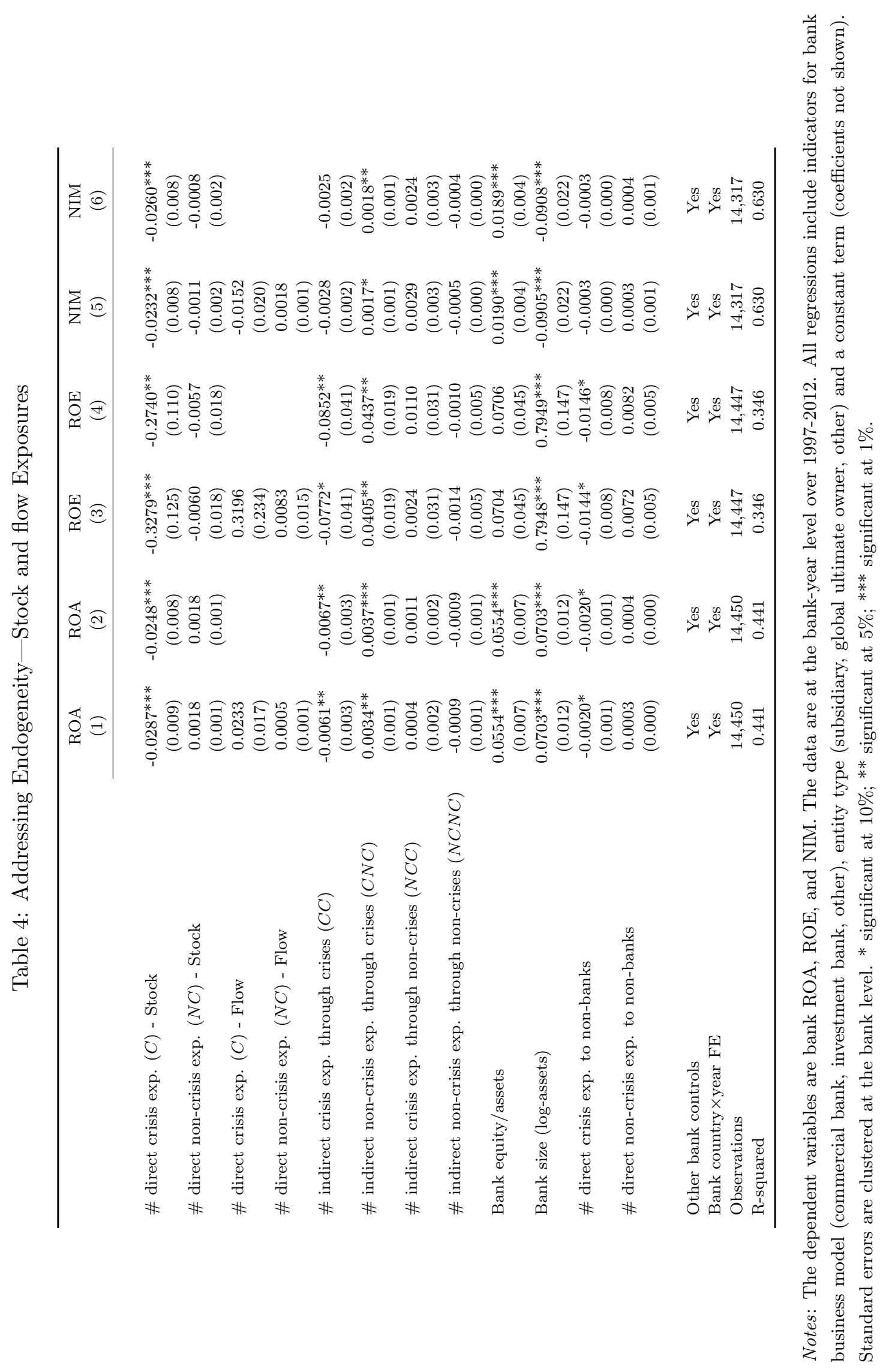




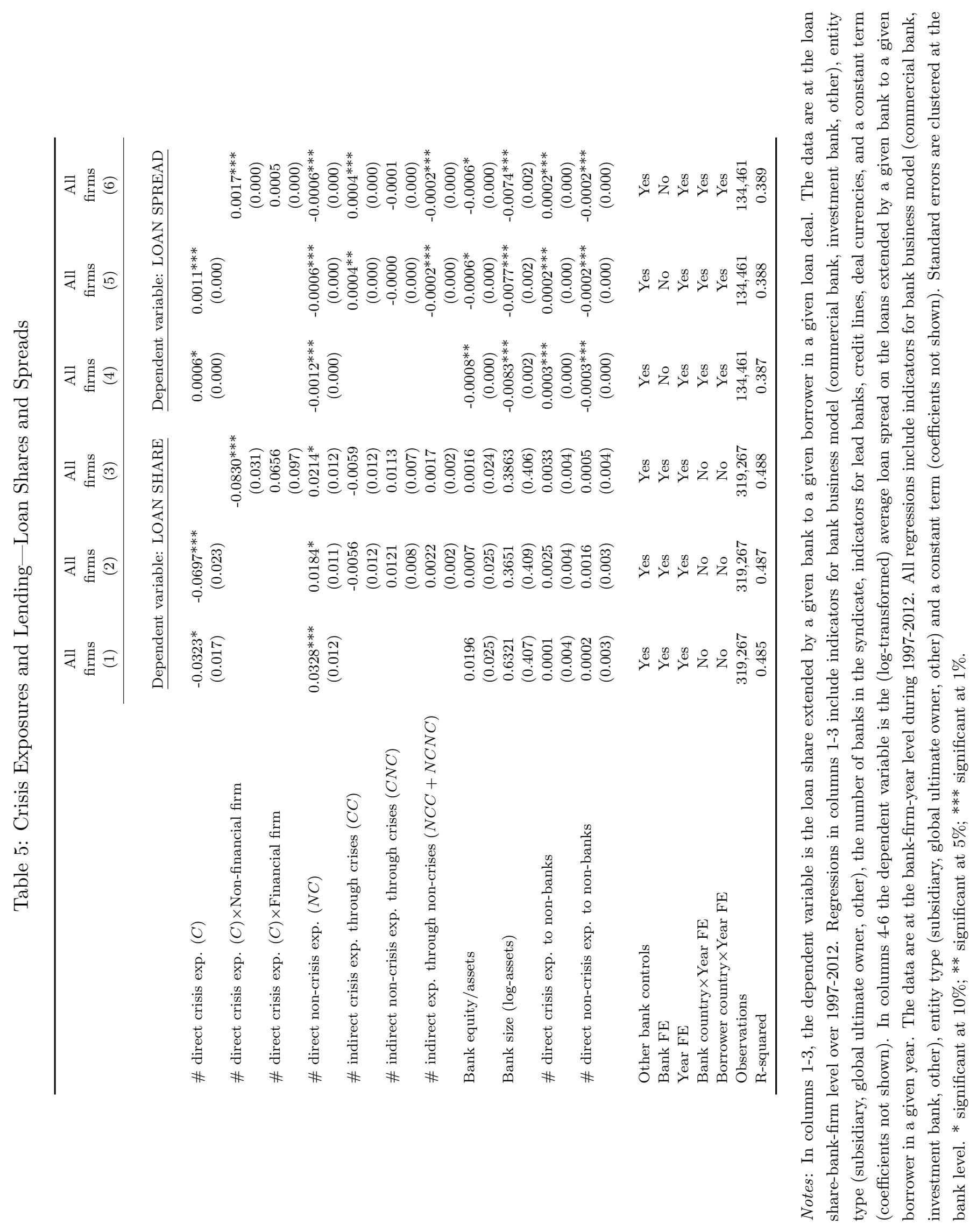




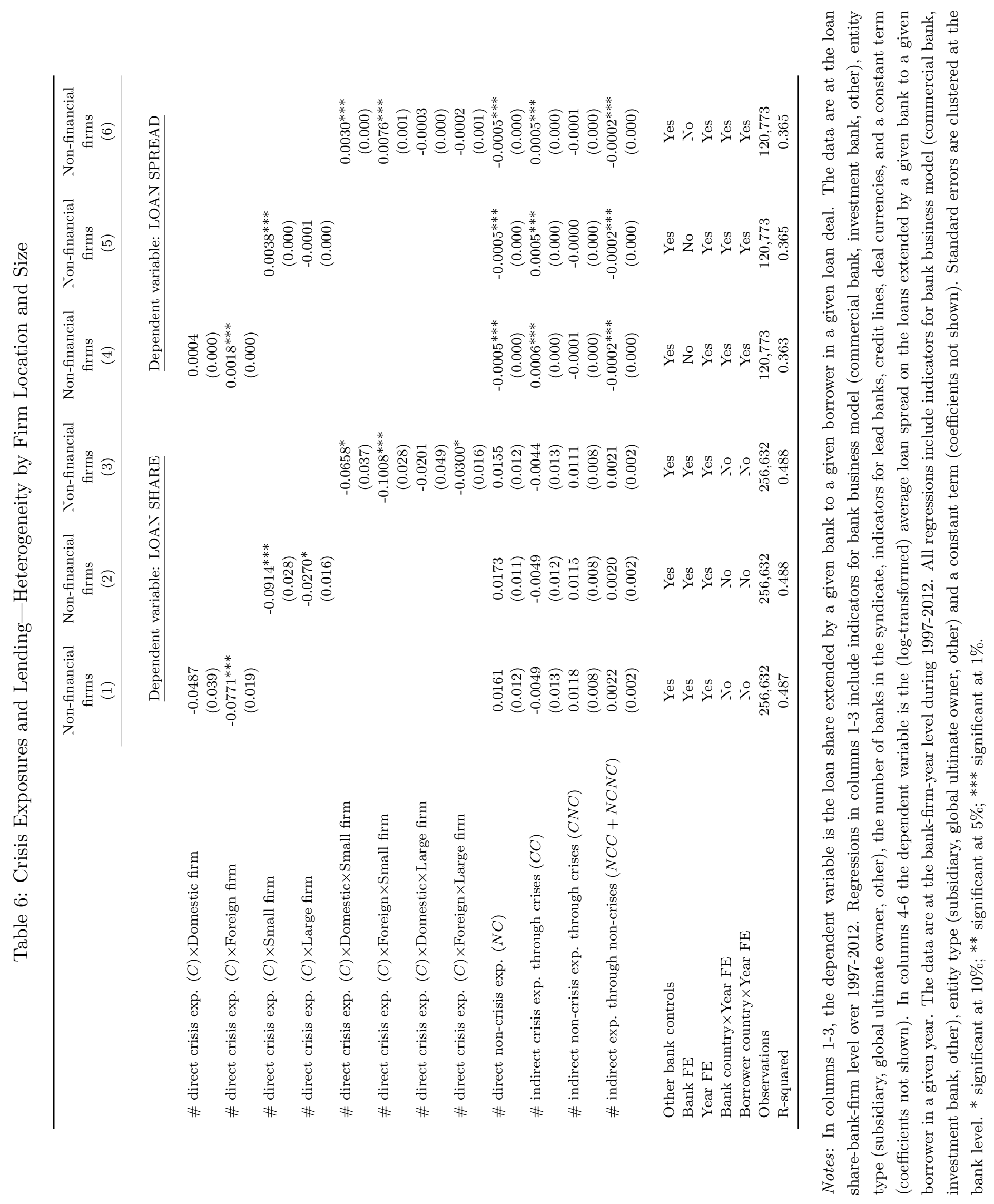




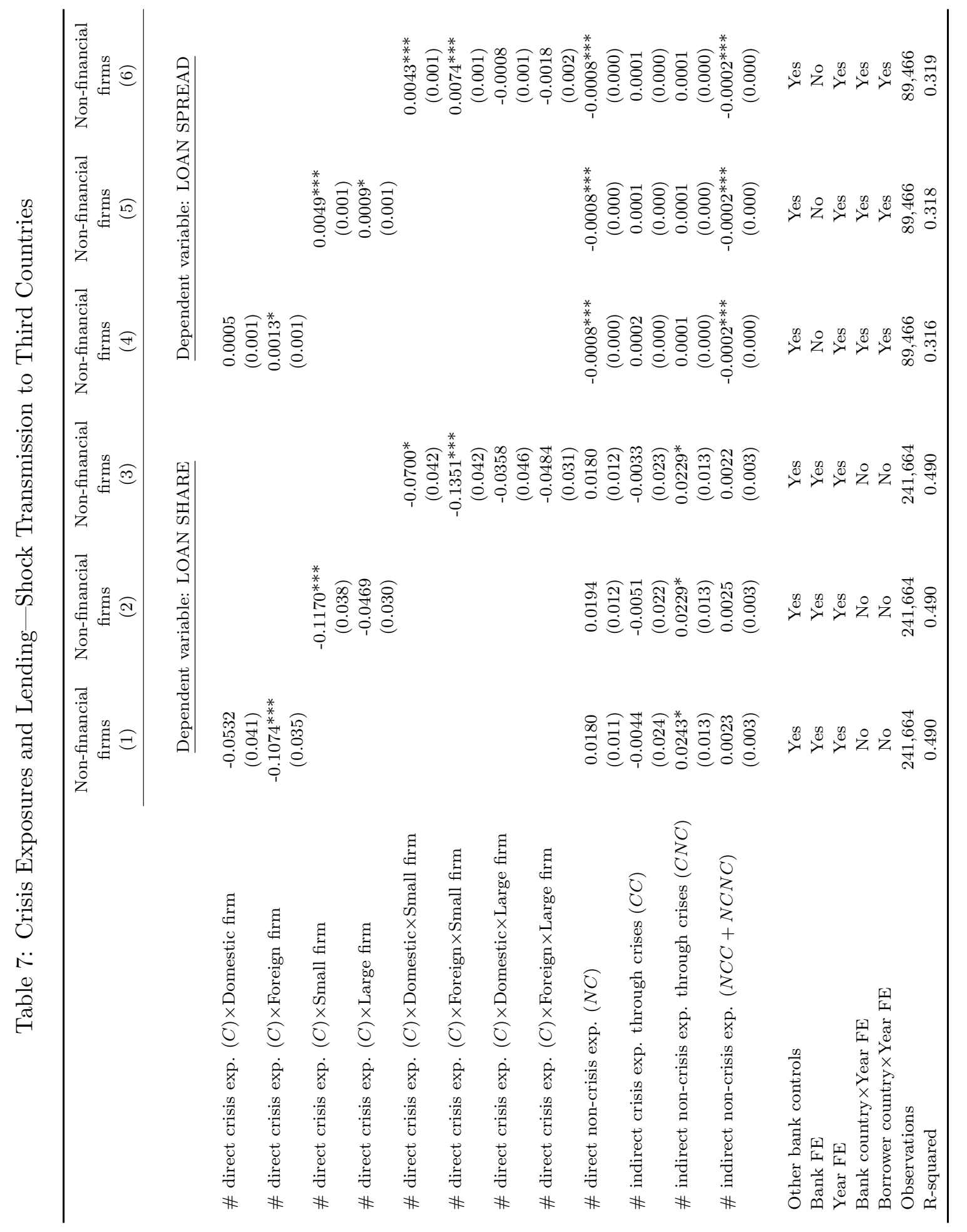

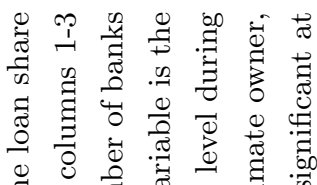

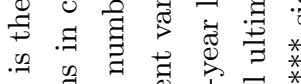

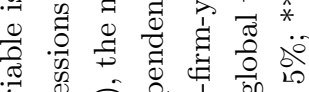

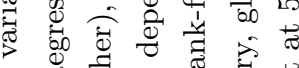
웜

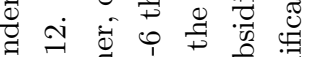

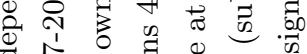

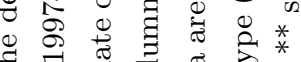

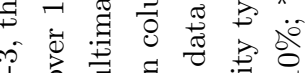

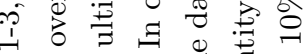

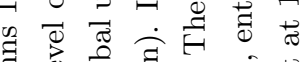

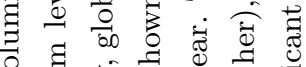

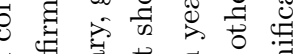

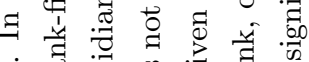

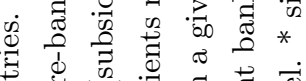

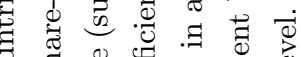
जी क्षे 됴 음

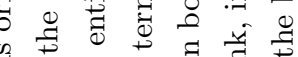

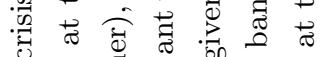

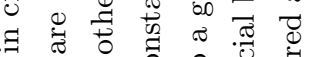
च एँ 要 霖

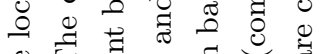
E

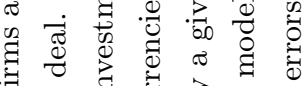

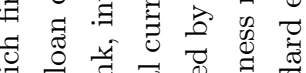

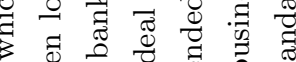
t5 का के 急

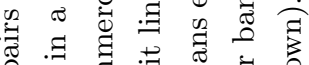
प둥 घ 类 政

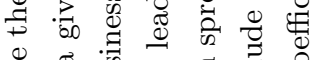

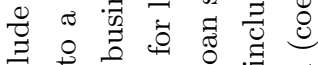
造

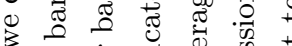

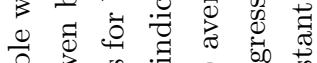

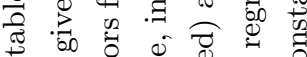

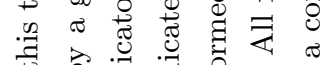
$\exists$ 菏 ชิ

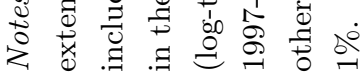


Table 8: Firm Real Outcomes-Crisis Exposures and Investment Ratio

\begin{tabular}{|c|c|c|c|c|}
\hline & $(1)$ & $(2)$ & $(3)$ & $(4)$ \\
\hline$\#$ direct crisis exp. $(C)$ & $\begin{array}{c}-0.0216^{* *} \\
(0.008)\end{array}$ & & & \\
\hline \# direct crisis exp. $(C) \times$ Small firm $[1]$ & & $\begin{array}{c}-0.0349^{*} \\
(0.016)\end{array}$ & $\begin{array}{c}-0.0431^{* *} \\
(0.018)\end{array}$ & $\begin{array}{l}-0.0341^{* * *} \\
\quad(0.007)\end{array}$ \\
\hline \# direct crisis exp. $(C) \times$ Large firm $[2]$ & & $\begin{array}{r}-0.0117 \\
(0.010)\end{array}$ & $\begin{array}{c}-0.0228^{*} \\
(0.011)\end{array}$ & $\begin{array}{c}-0.0298^{* * *} \\
(0.007)\end{array}$ \\
\hline \# direct non-crisis exp. $(N C)$ & $\begin{array}{r}-0.0089 \\
(0.007)\end{array}$ & $\begin{array}{r}-0.0096 \\
(0.007)\end{array}$ & $\begin{array}{r}-0.0056 \\
(0.005)\end{array}$ & $\begin{array}{r}-0.0051 \\
(0.005)\end{array}$ \\
\hline \# indirect crisis exp. through crises $(C C)$ & & & $\begin{array}{r}-0.0133 \\
(0.017)\end{array}$ & $\begin{array}{r}-0.0071 \\
(0.013)\end{array}$ \\
\hline \# indirect non-crisis exp. through crises $(C N C)$ & & & $\begin{array}{l}0.0093 \\
(0.008)\end{array}$ & $\begin{array}{l}0.0075 \\
(0.007)\end{array}$ \\
\hline \# indirect exp. through non-crises $(N C C+N C N C)$ & & & $\begin{array}{r}-0.0016 \\
(0.002)\end{array}$ & $\begin{array}{r}-0.0012 \\
(0.002)\end{array}$ \\
\hline Bank equity/assets & $\begin{array}{r}-0.0025 \\
(0.011)\end{array}$ & $\begin{array}{r}-0.0023 \\
(0.010)\end{array}$ & $\begin{array}{l}0.0011 \\
(0.009)\end{array}$ & $\begin{array}{l}0.0018 \\
(0.005)\end{array}$ \\
\hline Bank size (log-assets) & $\begin{array}{r}0.1297^{*} \\
(0.066)\end{array}$ & $\begin{array}{r}0.1314^{*} \\
(0.065)\end{array}$ & $\begin{array}{r}0.1422^{*} \\
(0.067)\end{array}$ & $\begin{array}{l}0.0986 \\
(0.083)\end{array}$ \\
\hline \# direct crisis exp. to non-banks & $\begin{array}{l}0.0012 \\
(0.002)\end{array}$ & $\begin{array}{l}0.0011 \\
(0.002)\end{array}$ & $\begin{array}{l}0.0004 \\
(0.001)\end{array}$ & $\begin{array}{c}-0.0001 \\
(0.001)\end{array}$ \\
\hline \# direct non-crisis exp. to non-banks & $\begin{array}{l}0.0005 \\
(0.001)\end{array}$ & $\begin{array}{l}0.0007 \\
(0.001)\end{array}$ & $\begin{array}{l}0.0010 \\
(0.001)\end{array}$ & $\begin{array}{l}0.0007 \\
(0.001)\end{array}$ \\
\hline Firm's Tobin's $q$ & $\begin{array}{c}0.0177^{* * *} \\
(0.003)\end{array}$ & $\begin{array}{c}0.0176^{* * *} \\
(0.002)\end{array}$ & $\begin{array}{c}0.0177^{* * * *} \\
(0.002)\end{array}$ & $\begin{array}{c}0.0177^{* * *} \\
(0.002)\end{array}$ \\
\hline Firm's cash flow-to-assets & $\begin{array}{l}0.0093 \\
(0.008)\end{array}$ & $\begin{array}{l}0.0088 \\
(0.008)\end{array}$ & $\begin{array}{l}0.0085 \\
(0.008)\end{array}$ & $\begin{array}{l}0.0115 \\
(0.014)\end{array}$ \\
\hline Firm's size (log-assets) & $\begin{array}{c}-1.4364^{* * *} \\
(0.093)\end{array}$ & $\begin{array}{c}-1.4622^{* * *} \\
(0.096)\end{array}$ & $\begin{array}{c}-1.4500^{* * *} \\
(0.097)\end{array}$ & $\begin{array}{c}-1.6246^{* * *} \\
(0.165)\end{array}$ \\
\hline Firm FE & Yes & Yes & Yes & Yes \\
\hline Firm country $\times$ Industry $\times$ Year FE & Yes & Yes & Yes & Yes \\
\hline Industry classification & 1-digit & 1-digit & 1-digit & 2-digit \\
\hline p-value t-test $[1]<[2]$ & & 0.090 & 0.104 & 0.176 \\
\hline Observations & 10,151 & 10,151 & 10,151 & 9,389 \\
\hline R-squared & 0.827 & 0.827 & 0.827 & 0.843 \\
\hline
\end{tabular}

Notes: The dependent variables is firm-level investment ratio (capex/lagged assets). The data are at the firmyear level over 1997-2012. All regressions include control variables for lenders' business model (commercial bank, investment bank, other), entity type (subsidiary, global ultimate owner, other), and a constant term (coefficients not shown). Standard errors are clustered at the firm level. * significant at $10 \% ;{ }^{* *}$ significant at $5 \%$; ** significant at $1 \%$. 
Table 9: Firm Real Outcomes-Crisis Exposures and Asset Growth

\begin{tabular}{|c|c|c|c|c|}
\hline & $(1)$ & $(2)$ & $(3)$ & $(4)$ \\
\hline \# direct crisis exp. $(C)$ & $\begin{array}{c}-0.1129^{* *} \\
(0.034)\end{array}$ & & & \\
\hline \# direct crisis exp. $(C) \times$ Small firm [1] & & $\begin{array}{c}-0.1278^{* *} \\
(0.053)\end{array}$ & $\begin{array}{c}-0.1498^{* *} \\
(0.053)\end{array}$ & $\begin{array}{c}-0.1123^{*} \\
(0.052)\end{array}$ \\
\hline \# direct crisis exp. $(C) \times$ Large firm $[2]$ & & $\begin{array}{c}-0.1018^{* *} \\
(0.041)\end{array}$ & $\begin{array}{c}-0.1124^{*} \\
(0.054)\end{array}$ & $\begin{array}{r}-0.0905 \\
(0.052)\end{array}$ \\
\hline \# direct non-crisis exp. $(N C)$ & $\begin{array}{r}-0.0469 \\
(0.040)\end{array}$ & $\begin{array}{r}-0.0476 \\
(0.041)\end{array}$ & $\begin{array}{r}-0.0031 \\
(0.032)\end{array}$ & $\begin{array}{r}-0.0036 \\
(0.024)\end{array}$ \\
\hline \# indirect crisis exp. through crises $(C C)$ & & & $\begin{array}{l}0.0357 \\
(0.063)\end{array}$ & $\begin{array}{l}0.0493 \\
(0.055)\end{array}$ \\
\hline \# indirect non-crisis exp. through crises $(C N C)$ & & & $\begin{array}{r}-0.0022 \\
(0.028)\end{array}$ & $\begin{array}{r}-0.0065 \\
(0.029)\end{array}$ \\
\hline \# indirect exp. through non-crises $(N C C+N C N C)$ & & & $\begin{array}{c}-0.0123 \\
(0.009)\end{array}$ & $\begin{array}{r}-0.0127 \\
(0.010)\end{array}$ \\
\hline Bank equity/assets & $\begin{array}{r}-0.0145 \\
(0.025)\end{array}$ & $\begin{array}{r}-0.0143 \\
(0.028)\end{array}$ & $\begin{array}{r}-0.0147 \\
(0.034)\end{array}$ & $\begin{array}{l}0.0016 \\
(0.044)\end{array}$ \\
\hline Bank size (log-assets) & $\begin{array}{l}0.1065 \\
(0.658)\end{array}$ & $\begin{array}{l}0.1085 \\
(0.656)\end{array}$ & $\begin{array}{l}0.0246 \\
(0.654)\end{array}$ & $\begin{array}{c}-0.1686 \\
(0.415)\end{array}$ \\
\hline \# direct crisis exp. to non-banks & $\begin{array}{l}0.0117 \\
(0.007)\end{array}$ & $\begin{array}{c}0.0116^{*} \\
(0.006)\end{array}$ & $\begin{array}{l}0.0093 \\
(0.007)\end{array}$ & $\begin{array}{l}0.0093 \\
(0.008)\end{array}$ \\
\hline \# direct non-crisis exp. to non-banks & $\begin{array}{l}0.0066 \\
(0.007)\end{array}$ & $\begin{array}{l}0.0068 \\
(0.007)\end{array}$ & $\begin{array}{l}0.0100 \\
(0.007)\end{array}$ & $\begin{array}{c}0.0127^{*} \\
(0.005)\end{array}$ \\
\hline Firm's Tobin's $q$ & $\begin{array}{c}0.1109^{* * *} \\
(0.009)\end{array}$ & $\begin{array}{c}0.1108^{* * * *} \\
(0.010)\end{array}$ & $\begin{array}{c}0.1106^{* * *} \\
(0.011)\end{array}$ & $\begin{array}{c}0.1110^{* * *} \\
(0.009)\end{array}$ \\
\hline Firm's cash flow-to-assets & $\begin{array}{c}0.1888^{* *} \\
(0.060)\end{array}$ & $\begin{array}{c}0.1883^{* *} \\
(0.062)\end{array}$ & $\begin{array}{c}0.1873^{* *} \\
(0.067)\end{array}$ & $\begin{array}{c}0.2146^{* * *} \\
(0.047)\end{array}$ \\
\hline Firm's size (log-assets) & $\begin{array}{c}-25.1019^{* * *} \\
(0.992)\end{array}$ & $\begin{array}{c}-25.1307^{* * * *} \\
(1.030)\end{array}$ & $\begin{array}{c}-25.1485^{* * *} \\
(1.029)\end{array}$ & $\begin{array}{c}-26.3104^{* * *} \\
(1.109)\end{array}$ \\
\hline Firm FE & Yes & Yes & Yes & Yes \\
\hline Firm country $\times$ Industry $\times$ Year FE & Yes & Yes & Yes & Yes \\
\hline Industry classification & 1-digit & 1-digit & 1-digit & 2-digit \\
\hline p-value t-test $[1]<[2]$ & & 0.301 & 0.234 & 0.351 \\
\hline Observations & 10,148 & 10,148 & 10,148 & 9,386 \\
\hline R-squared & 0.583 & 0.583 & 0.584 & 0.609 \\
\hline
\end{tabular}

Notes: The dependent variables is asset growth. The data are at the firm-year level over 1997-2012. All regressions include control variables for lenders' business model (commercial bank, investment bank, other), entity type (subsidiary, global ultimate owner, other), and a constant term (coefficients not shown). Standard errors are clustered at the firm level. $*$ significant at $10 \%$; ** significant at $5 \% ; * * *$ significant at $1 \%$. 


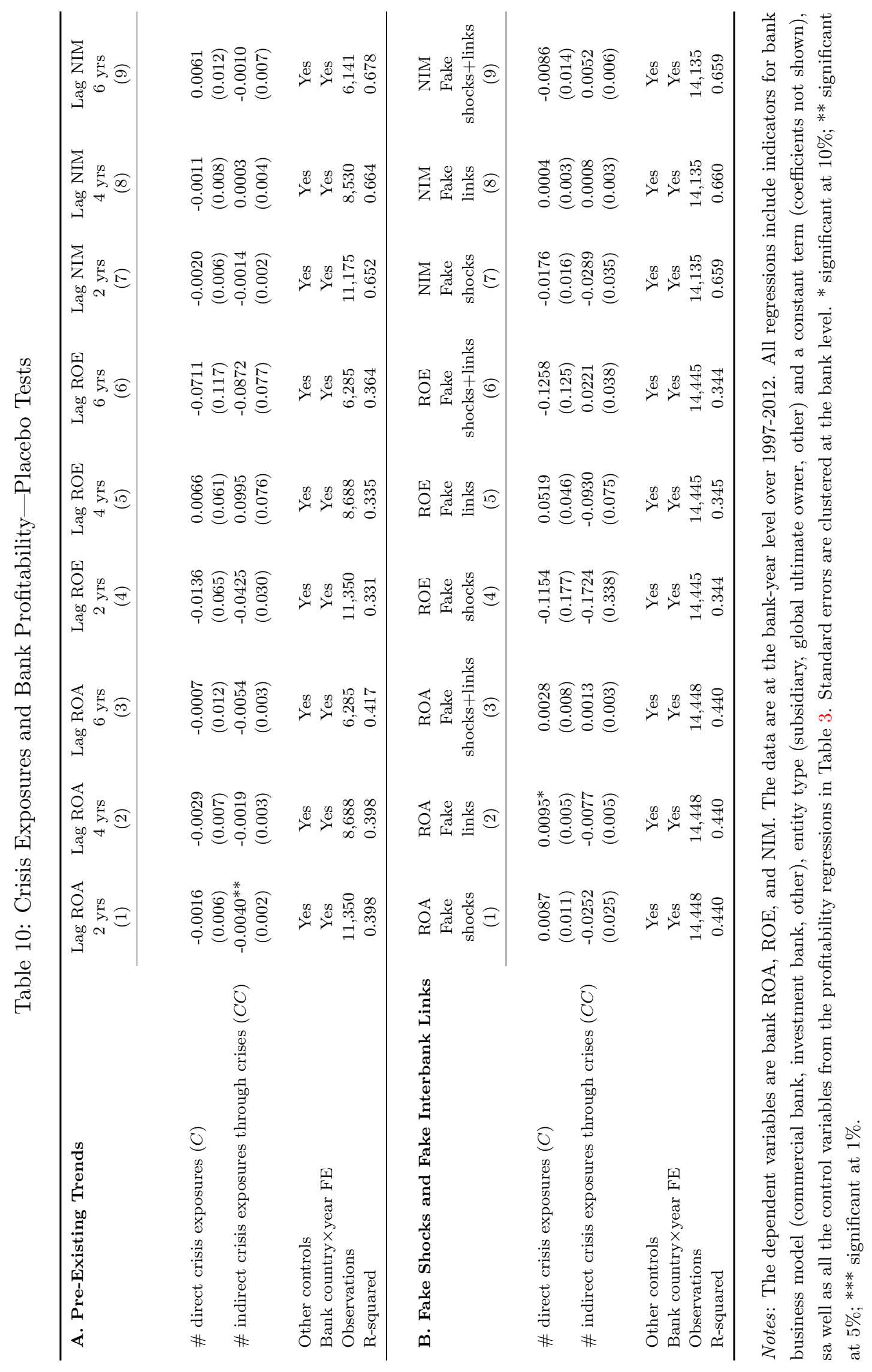




\section{Appendix (not for publication)}

\section{A-I Shock transmission mechanism}

Here we show how a simple shock transmission mechanism gives rise to our specifications. Assume that bank performance can be measured by $Y$, and let the exposure of bank $i$ to bank $j_{1}$ be denoted by $E_{i j_{1}}$, where $E$ is an indicator for the presence of an exposure. Let $C r_{i}$ denote an indicator for a financial crisis in the country of bank $i$ and $X_{i}$ denote the $(1 \times \mathrm{K})$ matrix of bank $i$ 's $\mathrm{K}$ characteristics. We hypothesize that the returns of bank $i$ can be written as follows (omitting the time subscript for simplicity):

$$
Y_{i}=\alpha+X_{i} \beta+\lambda C r_{i}+\gamma \sum_{j_{1}} E_{i j_{1}} Y_{j_{1}}
$$

Note that the performance of bank $i, Y_{i}$, is a function of its own characteristics, $X_{i}$ and $C r_{i}$, and the performance of the banks $\left(j_{1} \mathrm{~s}\right)$ to which it is exposed. ${ }^{24}$ Equation 1 can be expanded infinitely and simplifies to:

$$
\begin{aligned}
Y_{i} & =\alpha+X_{i} \beta+\lambda C r_{i}+\gamma \sum_{j_{1}} E_{i j_{1}} \alpha+\gamma \sum_{j_{1}} E_{i j_{1}} X_{j_{1}} \beta+\gamma \sum_{j_{1}} E_{i j_{1}} \lambda C r_{j_{1}} \\
& +\gamma^{2} \sum_{j_{1}} \sum_{j_{2}} E_{i j_{1}} E_{j_{1} j_{2}} \alpha+\gamma^{2} \sum_{j_{1}} \sum_{j_{2}} E_{i j_{1}} E_{j_{1} j_{2}} X_{j_{2}} \beta+\gamma^{2} \sum_{j_{1}} \sum_{j_{2}} E_{i j_{1}} E_{j_{1} j_{2}} \lambda C r_{j_{2}}+\ldots \\
& +\gamma^{n} \sum_{j_{1}} \ldots \sum_{j_{n}} E_{i j_{1}} E_{j_{1} j_{2}} \ldots E_{j_{n-1} j_{n}} \alpha+\gamma^{n} \sum_{j_{1}} \ldots \sum_{j_{n}} E_{i j_{1}} E_{j_{1} j_{2}} \ldots E_{j_{n-1} j_{n}} X_{j_{n}} \beta+ \\
& +\gamma^{n} \sum_{j_{1}} \ldots \sum_{j_{n}} E_{i j_{1}} E_{j_{1} j_{2}} \ldots E_{j_{n-1} j_{n}} \lambda C r_{j_{n}}
\end{aligned}
$$

where $j_{1}$ represents the direct (first-degree) connections of bank $i, j_{2}$ represents the indirect (second-degree) connections of bank $i$ etc., and $n$ is the highest-degree (indirect) connection of bank $i$. Note that the union of the sets of first-degree connections of all $j_{1}$ banks corresponds to the set of second-degree connections of bank $i$. Equation 2 shows how the performance of bank $i$ depends on its direct and indirect exposures to borrowers in all countries, and especially in countries that are experiencing banking crises.

Based on Equation 2, a complete empirical specification would link measures of bank performance to bank controls, an indicator for the location of a bank in a country experiencing a banking crisis,

\footnotetext{
${ }^{24}$ Empirical tests of Equation 1 that regress bank profitabilty (ROA, ROE, NIM) on average bank profitability of counterparty banks deliver statistically significant coefficients on average counterparty bank profitability at the conventional levels, controlling for bank variables (capital, size, and indicators for bank business model and entity type) as well as bank country and year fixed effects.
} 
the bank's first, second, and higher-degree exposures, and the characteristics of all counterparty banks. The coefficient $\gamma^{n}$ decays exponentially and hence drastically reduces the potential impact of higher-degree connections. For this reason, in the implementation of Equation 2 we include only first and second-degree exposures. ${ }^{25}$

Adding subscripts for time $t$ and bank country $h$, and allowing constant $\alpha$ to vary by bank country and year $\left(\alpha_{h t}\right)$, the most complete specifications are as follows:

$$
\begin{aligned}
Y_{i t} & =\alpha_{h t}+X_{i t} \beta_{0}+\sum_{j_{1}} E_{i j_{1} t} X_{j_{1} t} \beta_{1}+\lambda_{1} \sum_{j_{1}} E_{i j_{1} t} C r_{j_{1} t}+\mu_{1} \sum_{j_{1}} E_{i j_{1} t} N C r_{j_{1} t} \\
& +\sum_{j_{1}} \sum_{j_{2}} E_{i j_{1} t} E_{j_{1} j_{2} t} X_{j_{2} t} \beta_{2}+\lambda_{2} \sum_{j_{1}} \sum_{j_{2}} E_{i j_{1} t} E_{j_{1} j_{2} t} C r_{j_{2} t}+\mu_{2} \sum_{j_{1}} \sum_{j_{2}} E_{i j_{1} t} E_{j_{1} j_{2} t} N C r_{j_{2} t}+\varepsilon_{i t},
\end{aligned}
$$

where $X_{i t}$ is a vector of bank characteristics, $C r_{j t}$ is a dummy variable that takes value 1 if country $j$ has a crisis in year $t$, and $N C r_{j t}$ is a dummy variable that takes value 1 if country $j$ does not have a crisis in year $t$. Subsequent terms refer to bank-level control variables and the number of bank borrowers in countries with systemic banking crises to which bank $i$ is exposed through its first- and second-degree connections. To arrive at this specification, observe that $\lambda_{1}=\gamma(\alpha+\lambda)$, $\mu_{1}=\gamma \alpha, \lambda_{2}=\gamma^{2}(\alpha+\lambda), \mu_{2}=\gamma^{2} \alpha$ from Equation 1 above. However, in estimating these coefficients separately, we relax the assumption of exponential decay with increased exposure distance. All variables enter the regressions contemporaneously.

When we estimate Equation 3 above we find that the characteristics of counterparty banks yield coefficients that are jointly statistically insignificant under most specifications. Therefore, we estimate parsimonious specifications without these characteristics, but our regression results are robust to their inclusion. (See Table A1 for bank profitability regressions that control for these characteristics.)

\footnotetext{
${ }^{25}$ There are no estimates on the size of $\gamma$ in interbank networks, but we can take some cues from the literature on shock propagation in production networks. Most models of production networks predict that the impact of firm-level shocks attenuates rapidly as they travel through production chains further from the source (Acemoglu, Carvalho, Ozdaglar and Tahbaz-Salehi, 2012), consistent with empirical evidence from the Great East Japan earthquake (Carvalho, Nirei, Saito and Tahbaz-Salehi, 2016). In the presence of additional financial frictions, Wu (2017) shows that "network effects" after firm-level shocks in the U.S. are persistent up to four connections away from the origins.
} 


\section{A-II Data Description}

To construct our bank-level dataset on cross-border interbank exposures and bank characteristics, we proceed as follows:

- Step 1. We download data on 170,274 individual loan deals signed between January 1990 and December 2012 from Dealogic's Loan Analytics. To construct the cross-border interbank exposures, we retain only the 16,526 loans extended from banks to banks. We drop the deals for which the lender is recorded as "unknown", "undisclosed syndicate", or "undisclosed investor (unknown)", as well as a small number of intra-group deals and deals that involve multiple borrowers (representing less than $1 \%$ of the sample). We also drop deals with missing maturity information and deals from lenders that are located in territories without an International Financial Statistics (IFS) code, namely Guernesey, Isle of Man, Jersey, and occupied Palestinian Territory. For lender country we use the variable "lender nationality" as reported in Dealogic Loan Analytics; for borrower country we use the variable "deal na-

tionality" after checking that the variable is correct by comparing banks that appear both as borrowers and lenders. We drop lenders that are classified as investment managers, special purpose vehicles, development banks, multilateral agencies, and miscellaneous. Bank borrowers are identified using the general industry group "Finance" and the sub-classifications commercial and savings banks, provincial banks, municipal banks, savings and loans, and investment banks.

- Step 2. Given that some bank names are recorded in Dealogic Loan Analytics with typos, or they refer to banks that have changed their name over time, or have been acquired by or merged with other banks, we clean up the bank names as follows:

- If a bank changed its name during 1990-2012, we retain its Bankscope name (as of end-2012) throughout the sample period.

- If two or more banks merged during the sample period to form a new bank, they are kept as distinct banks until the year of the merger and cease to exist after the merger; the bank resulting from the merger is kept subsequent to the merger.

- If a bank was acquired by another bank, it appears as a distinct bank until the year of the acquisition.

- Lending from multiple branches of the same bank in a foreign country is aggregated. 
- Lending from off-shore branches of a bank is aggregated.

- Step 3. After cleaning the bank names, we hand-match all the banks on a locational basis, by name and country, with balance sheet data from Bankscope. We use various sources to learn the institutional history of banks and make correct matches, including banks' corporate websites, the Federal Reserve Board National Information Center website ${ }^{26}$ and Bloomberg Businessweek. $^{27}$ Subsidiaries, branches, and other banking group entities for which there is balance sheet information in Bankscope are treated as distinct entities and are not linked to their parent financials.

Cross-border interbank exposures are constructed for the 6,083 banks that appear as lenders or borrowers in the loans granted during 1990-2012. After merging these banks with financial statement information from Bankscope, and removing banks with missing data, we are left with 1,869 banks. Then we construct cross-border interbank exposures using information on lender and borrower identity, loan amount, and loan maturity. Loans are treated as non-amortizing bullet loans. We use the same approach to construct cross-border exposures for each bank-borrower pair where borrowers are banks or non-banks (i.e., non-financial firms or sovereigns). In network terminology, cycles are not allowed in the computation of second-degree exposures.

In the empirical analysis we use the number of crisis and non-crisis exposures as opposed to their dollar value to limit measurement error. For the specifications that require loan shares (e.g., Tables 5-7), we use the actual shares as reported when available. When loan shares are not available, we estimate them following the regression-based approaches based on de Haas and van Horen (2013) and Kapan and Minoiu (2013). Specifically, we predict them on the basis of a regression model that is estimated on the sample of loans with reported shares. The dependent variable is the loan share and the regressors are loan amount $(\log )$, syndicate size, as well as dummies for loan currency, firm country, firm industry, bank role (lead vs. non-lead), bank country, and year:quarter. The model has an adjusted R-squared of close to $75 \%$. The results are robust to the approach of Duchin and Sosyura (2014), in which missing shares are imputed as follows: for lead banks, we use the mean share of the lead bank in the sample of loans with reported shares, and for simple participants we split the remainder of the loan in equal shares.

\footnotetext{
${ }^{26}$ http://www.ffiec.gov/nicpubweb/nicweb/SearchForm.aspx

27 http://investing.businessweek.com/research/company/overview/overview.asp
} 


\section{A-III Additional Results}

Table A1: Crisis exposures and bank profitability-Controlling for the characteristics of counterparty banks

\begin{tabular}{|c|c|c|c|c|c|c|}
\hline & $\begin{array}{c}\text { ROA } \\
(1)\end{array}$ & $\begin{array}{c}\text { ROA } \\
(2)\end{array}$ & $\begin{array}{c}\text { ROE } \\
(3)\end{array}$ & $\begin{array}{l}\mathrm{ROE} \\
(4)\end{array}$ & $\begin{array}{l}\text { NIM } \\
(5)\end{array}$ & $\begin{array}{l}\text { NIM } \\
(6)\end{array}$ \\
\hline \# direct crisis exposures $(C)$ & $\begin{array}{c}-0.0216^{* *} \\
(0.009)\end{array}$ & $\begin{array}{c}-0.0170^{*} \\
(0.009)\end{array}$ & $\begin{array}{c}-0.2415^{*} \\
(0.124)\end{array}$ & $\begin{array}{r}-0.1477 \\
(0.115)\end{array}$ & $\begin{array}{c}-0.0230^{* * *} \\
(0.008)\end{array}$ & $\begin{array}{c}-0.0183^{* *} \\
(0.009)\end{array}$ \\
\hline \# direct non-crisis exposures $(N C)$ & $\begin{array}{l}0.0011 \\
(0.002)\end{array}$ & $\begin{array}{c}0.0035^{*} \\
(0.002)\end{array}$ & $\begin{array}{r}-0.0001 \\
(0.024)\end{array}$ & $\begin{array}{c}0.0056 \\
(0.028)\end{array}$ & $\begin{array}{r}-0.0020 \\
(0.002)\end{array}$ & $\begin{array}{c}-0.0004 \\
(0.003)\end{array}$ \\
\hline \# indirect crisis exposures through crises $(C C)$ & & $\begin{array}{c}-0.0067^{* *} \\
(0.003)\end{array}$ & & $\begin{array}{c}-0.1006^{* *} \\
(0.048)\end{array}$ & & $\begin{array}{r}-0.0035 \\
(0.002)\end{array}$ \\
\hline \# indirect non-crisis exposures through crises $(C N C)$ & & $\begin{array}{c}0.0046^{* * *} \\
(0.002)\end{array}$ & & $\begin{array}{c}0.0439^{*} \\
(0.023)\end{array}$ & & $\begin{array}{c}0.0019^{*} \\
(0.001)\end{array}$ \\
\hline$\#$ indirect exp. through non-crises $(N C C+N C N C)$ & & $\begin{array}{c}-0.0004 \\
(0.000)\end{array}$ & & $\begin{array}{r}-0.0003 \\
(0.006)\end{array}$ & & $\begin{array}{r}-0.0007 \\
(0.000)\end{array}$ \\
\hline Bank equity/assets & $\begin{array}{c}0.0554^{* * *} \\
(0.007)\end{array}$ & $\begin{array}{c}0.0554^{* * *} \\
(0.007)\end{array}$ & $\begin{array}{l}0.0717 \\
(0.045)\end{array}$ & $\begin{array}{l}0.0715 \\
(0.045)\end{array}$ & $\begin{array}{c}0.0165^{* * *} \\
(0.004)\end{array}$ & $\begin{array}{c}0.0165^{* * *} \\
(0.004)\end{array}$ \\
\hline Bank size (log-assets) & $\begin{array}{c}0.0703^{* * *} \\
(0.012)\end{array}$ & $\begin{array}{c}0.0695^{* * *} \\
(0.012)\end{array}$ & $\begin{array}{c}0.7974^{* * *} \\
(0.150)\end{array}$ & $\begin{array}{c}0.7963^{* * *} \\
(0.150)\end{array}$ & $\begin{array}{c}-0.0917^{* * *} \\
(0.022)\end{array}$ & $\begin{array}{c}-0.0919^{* * *} \\
(0.022)\end{array}$ \\
\hline \# direct crisis exposures to non-banks & $\begin{array}{r}-0.0017 \\
(0.001)\end{array}$ & $\begin{array}{c}-0.0023^{* *} \\
(0.001)\end{array}$ & $\begin{array}{c}-0.0153^{*} \\
(0.008)\end{array}$ & $\begin{array}{c}-0.0188^{* *} \\
(0.008)\end{array}$ & $\begin{array}{r}-0.0001 \\
(0.000)\end{array}$ & $\begin{array}{r}-0.0005 \\
(0.001)\end{array}$ \\
\hline \# direct non-crisis exposures to non-banks & $\begin{array}{r}-0.0000 \\
(0.000)\end{array}$ & $\begin{array}{l}0.0003 \\
(0.000)\end{array}$ & $\begin{array}{c}0.0094^{*} \\
(0.005)\end{array}$ & $\begin{array}{c}0.0085 \\
(0.006)\end{array}$ & $\begin{array}{l}0.0005 \\
(0.001)\end{array}$ & $\begin{array}{l}0.0008 \\
(0.001)\end{array}$ \\
\hline Other controls & Yes & Yes & Yes & Yes & Yes & Yes \\
\hline Bank country $\times$ year $F E$ & Yes & Yes & Yes & Yes & Yes & Yes \\
\hline Observations & 14,448 & 14,448 & 14,445 & 14,445 & 14,135 & 14,135 \\
\hline $\begin{array}{l}\text { R-squared } \\
\text { p-value: joint insignificance of counterparty }\end{array}$ & 0.441 & 0.441 & 0.346 & 0.346 & 0.659 & 0.659 \\
\hline bank characteristics & 0.0662 & 0.109 & 0.223 & 0.597 & 0.374 & 0.215 \\
\hline \# banks & 1869 & 1869 & 1869 & 1869 & 1849 & 1849 \\
\hline
\end{tabular}

Notes: This table examines the robustness of the bank profitability results (for ROA, ROE, and NIM) to controlling for the characteristics of first-degree and second-degree counterparty banks. The characteristics of counterparty banks include direct and indirect exposures to banks and non-banks, capital, size, business model and entity type (coefficients are not shown). All regressions also include indicators for bank business model (commercial bank, investment bank, other), entity type (subsidiary, global ultimate owner, other) and a constant term (coefficients are not shown). Standard errors are clustered at the bank level. ${ }^{*}$ significant at $10 \% ;{ }^{* *}$ significant at $5 \% ;{ }^{* * *}$ significant at $1 \%$. 


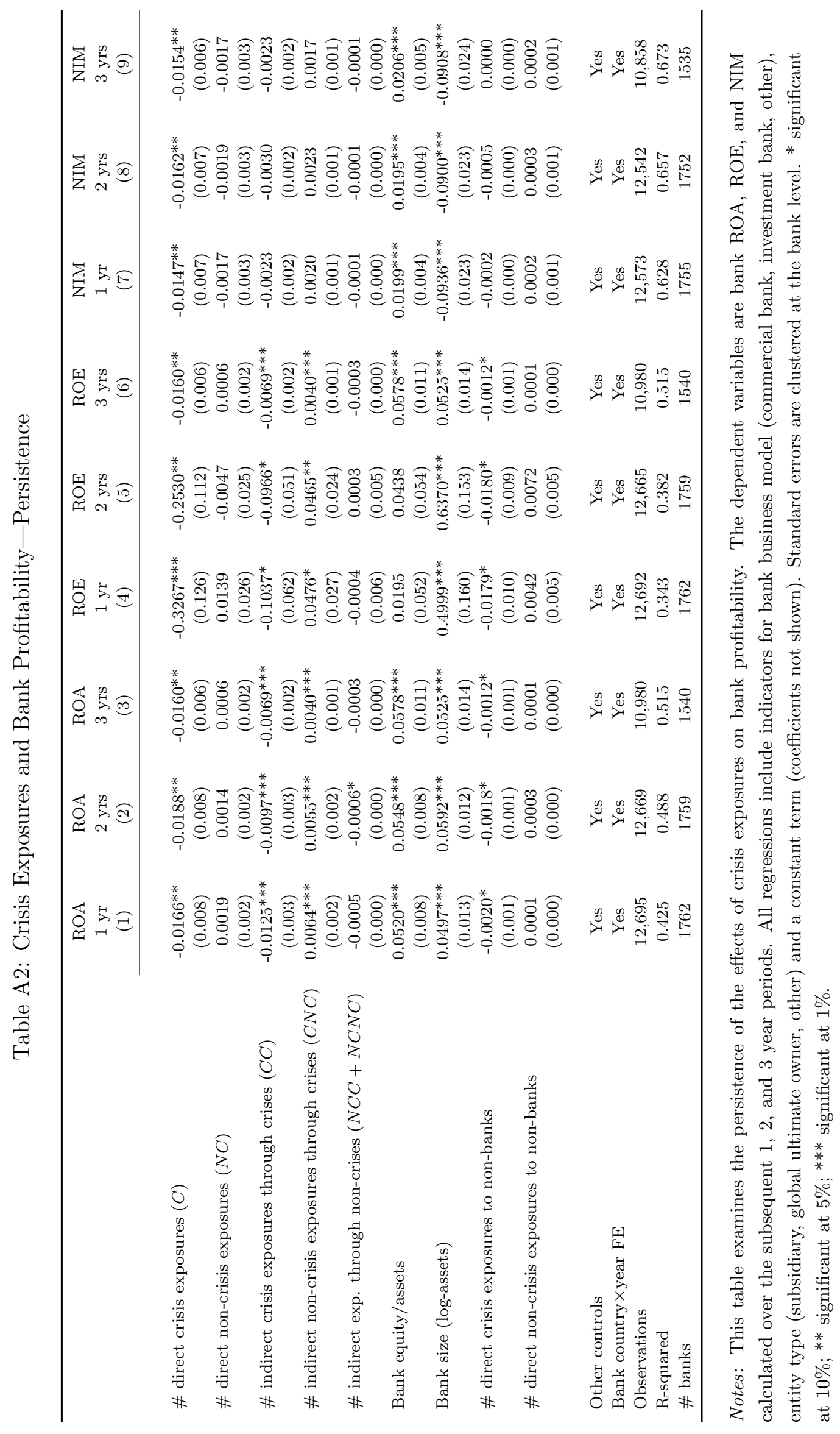




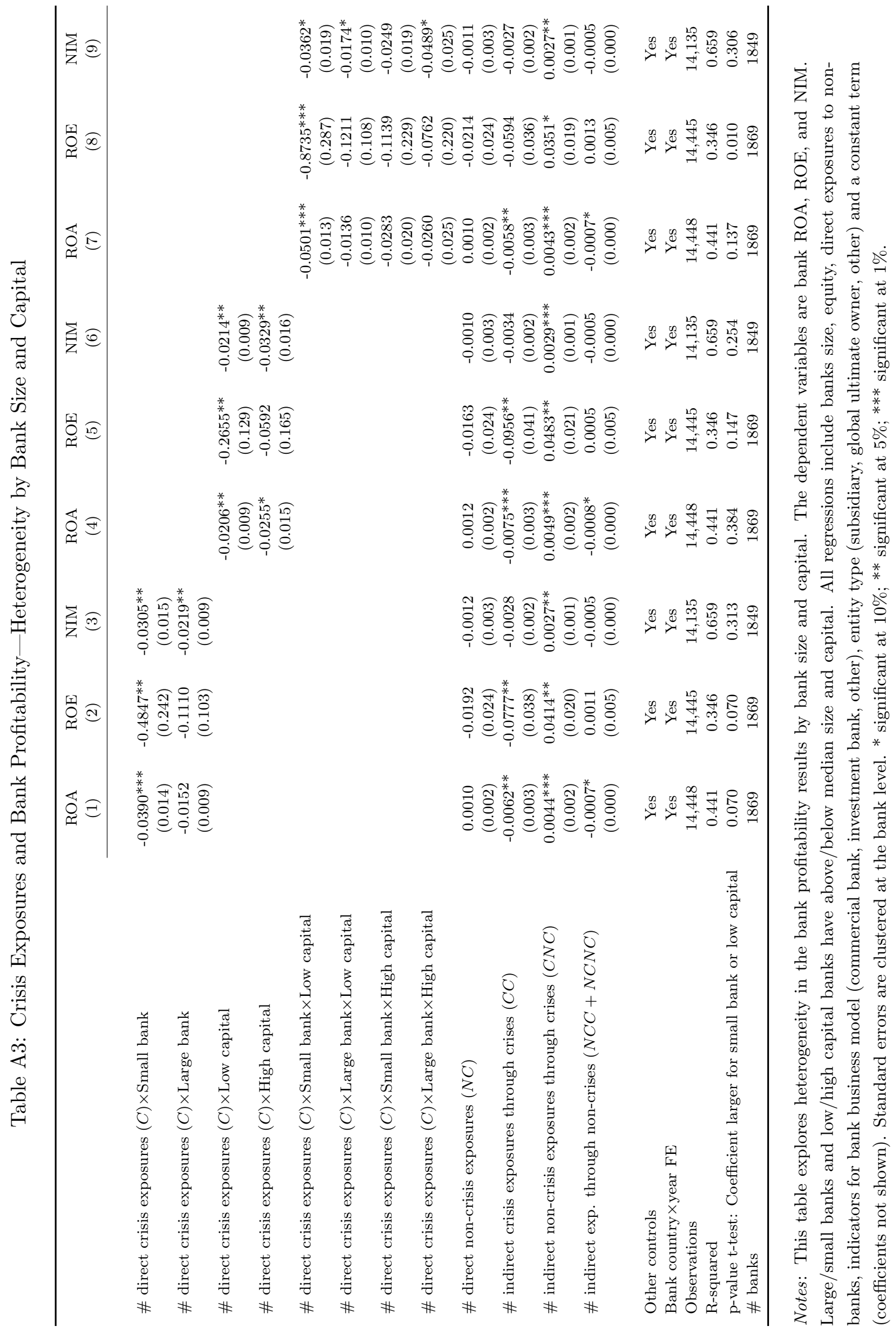

